\title{
Economic cycle and deceleration of female labor force participation in Latin America
}

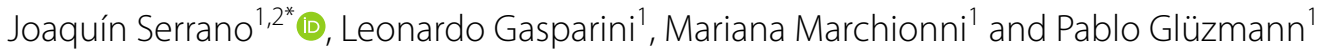

\begin{abstract}
We study the behavior of female labor force participation (LFP) over the business cycle by estimating fixed effects models at the country and population-group level, using data from harmonized national household surveys of 18 Latin American countries in the period 1987-2014. We find that female LFP follows a countercyclical pattern-especially in the case of married, with children and vulnerable women - which suggests the existence of an inverse added-worker effect. We argue that this factor may have contributed to the deceleration in female labor supply in Latin America that took place in the 2000s, a decade of unusual high economic growth.
\end{abstract}

Keywords: Economic cycle, Female labor force participation, Latin America

JEL classification: J22, J16, N3

\section{Introduction}

Over more than 50 years female labor force participation (LFP) has been increasing markedly and steadily in almost all regions of the world. Latin America has not been an exception: about 70 million women entered the labor market during the second half of the 20th century, reflecting the increasingly important role of women in the region (Chioda 2011). However, since the early 2000s the growth of female LFP has slowed down significantly in most Latin American countries and it has even come to a halt in some of them. While the growth of female LFP was on average 0.91 percentage points a year between 1992 and 2002, it slowed down to 0.35 points a year between 2002 and 2014. This deceleration has occurred despite both a large increase in the level of schooling of women and a decline in fertility levels, two factors that should favor the increase in female labor supply (Gasparini and Marchionni 2015; Beccaria et al. 2015).

The recent slowdown in the growth rate of women's labor supply may affect their prospects for empowerment in society (World Bank 2012), postpone the reduction of gender gaps in the labor market, and even undermine

\footnotetext{
*Correspondence: serranojqn@gmail.com

2 Departamento de Economía, FCE-UNLP, Oficina 322, Calle 6 No 777,

1900 La Plata, Argentina

Full list of author information is available at the end of the article
}

the goals of reducing poverty and income inequality in the region (Parada et al. 2017). It could also imply a stagnation of the global labor supply, given the absence of significant changes in male labor force participation (Beccaria et al. 2015).

The strong and rather unexpected economic expansion that Latin America experienced in the 2000s, well above the long-term trend, has been pointed out as one of the likely driving factors of the slowdown in female LFP (Gasparini and Marchionni 2017). Better macroeconomic conditions can affect the entry of women into the labor market at least in two different ways, with effects in opposite directions. On the one hand, a better economic context can encourage women to enter the labor market, as they face more favorable labor conditions and higher wages (substitution effect). On the other hand, a better economic scenario may imply lower unemployment and higher earnings of male partners and the expansion of social safety nets, two factors that alleviate the pressure on other family members, especially female spouses, to look for a job, and hence negatively affect their LFP (income effect). This latter channel, a version of the typical added-worker effect, could have been more relevant for women in vulnerable households in Latin America, since (i) their labor supply is more elastic to income shocks, either coming from earned or unearned income, 
and (ii) their households were the most benefitted by the economic changes in the 2000s.

In this paper we use a large dataset of microdata from harmonized household surveys of all Latin American countries to provide evidence on the empirical links between labor force participation and the cycle and trend components of GDP, and use the results to argue about the likely driving factors behind the observed deceleration in female LFP in the region. In particular, and unlike Gasparini and Marchionni (2017) that carry out an analysis based on observations at the country level, we estimate fixed effects models of LFP based on a panel that follows groups of individuals defined according to their level of schooling and age in each Latin American country over the period 1987-2014. Working at a population-group level allows us to incorporate a broad set of regressors, combining variables linked to the macroeconomic context (cyclical and trend components of GDP) with others related to demographic characteristics and public policies.

We find that whereas female LFP is positively associated with the trend component of GDP, it has a countercyclical behavior: large short-term expansions of GDP, beyond its long-term increasing trend, are associated with a reduction in female labor supply. The evidence is consistent with an inverse added-worker effect: better economic conditions for primary workers cause a delay in secondary workers' entrance into the labor market. This relationship is stronger for married women (either in formal or consensual unions) with young children, who often act as secondary workers in their households, especially those with low educational attainment, living in rural areas, and from low-income families. These results are consistent with the hypothesis that the exceptionally high economic growth in Latin America in the 2000s is a relevant factor behind the deceleration in female LFP, which was particularly intense among vulnerable married women.

The rest of the paper is organized as follows. We begin in Sect. 2 by briefly reviewing the literature on the determinants of female LFP in Latin America. Section 3 describes the data sources that are used in the study. In Sect. 4 we present preliminary evidence on the association between the economic cycle and the recent deceleration of female LFP in the region. Section 5 describes the empirical strategy and Sect. 6 reports and discusses the results. In Sect. 7 we conclude with some final remarks.

\section{Background}

Disentangling all the factors that may account for the observed patterns in female labor supply is not an easy task, since several potential driving forces are simultaneously at play. Busso and Romero Fonseca (2015) and Chioda (2011) present a broad conceptual framework, which divides the possible determinants of female LFP into two groups: those that depend on individual decisions and preferences, and those that are out of the individual's control. The first group includes the decisions associated with human capital investment (education) and family formation (marriage, fertility). The second group comprises the returns in the labor market (e.g. gender wage gaps), household technologies (availability of home appliances, electricity and internet connection), health technologies (contraceptive methods), cultural factors (religion, gender discrimination), and public policies (taxes, cash transfers, children and elderly care services, maternity and parental leave). ${ }^{1}$ The variables that we are most interested in are those related to macroeconomic conditions, which are part of the second group of factors, such as the trend and cycle components of GDP.

A strand of the literature studies the role of macroeconomic conditions by estimating the effect of recessions and economic crises on the aggregate rate of female LFP. In particular, these works try to assess the relevance of the addedworker effect (AWE). The concept was originally conceived by Woytinsky (1940) and later developed by Ashenfelter (1980), Heckman and Macurdy (1980), Lundberg (1985) and Maloney (1987). The AWE refers to the entry into the labor market of household secondary workers, usually wives, after a transitory reduction in household income (e.g. after the household head becomes unemployed). ${ }^{2}$ Thus, the relevance of the AWE with regard to female LFP relies on a typical income effect that arises at the household level in the context of a unitary model that assumes that women are secondary workers and that leisure is a normal good. In the context of life cycle models with no liquidity constraints, the AWE is expected to be negligible as long as the loss in income due to unemployment is small compared to the primary worker's lifetime earnings (Lundberg 1985).

In addition to the income effect represented by the AWE, unfavorable economic perspectives in the labor market may lead to a substitution effect known in the literature as the discouraged worker effect, which operates in the opposite direction. If the latter is outweighed by the

\footnotetext{
${ }^{1}$ Busso and Romero Fonseca (2015) apply a meta-analysis of the determinants of women's labor supply and estimate bivariate models with country fixed effects to assess the role of each factor in explaining the evolution of female LFP in Latin America. Their results suggest that the positive long-term trend is driven primarily by the expansion of health and household technologies and by the gradual change in cultural factors. Furthermore, traditional factors such as the increasing female educational attainment and the decreasing fertility rates have also contributed to the long-term expansion of female participation in the labor force and vice versa. Other works reach similar conclusions using aggregate decompositions, such as Peña et al. (2013) for Colombia or Gasparini et al. (2015) for several countries in Latin America.

2 In turn, the effect can be boosted if the increase in time away from the labor market of primary workers reduces the opportunity cost of carrying out market activities for secondary female workers, through the substitution of tasks within the household.
} 
AWE, female labor force participation should exhibit a countercyclical behavior.

In practice, the strength of these effects depends on the relevance of other factors, such as the availability of alternative strategies to cope with negative income shocks (child labor, unemployment insurance, etc.) and the existence of imperfect credit markets together with liquidity constraints (Mankart and Oikonomou 2017; Garcia-Perez and Rendon 2016). Consequently, empirical studies for developed countries, such as the U.S. or the United Kingdom, find small added-worker effects (Cullen and Gruber 2000; Stephens 2002; Prieto-Rodriguez and Rodriguez-Gutierrez 2003; Bredtmann et al. 2017), or even no evidence of its existence (Layard et al. 1980; Maloney 1991). Instead, in developing economies such as those of Latin America, the AWE may be larger due to the lack of unemployment insurance benefits, the fact that many households face financial restrictions, and the role of women as secondary workers, reinforced by solid family structures with a strong attachment to traditional gender roles, and low levels of women's skills and educational attainment within some population groups. In addition, given the importance of the informal sector in the region, entry and exit barriers in the labor market are relatively low, which facilitates changes in female participation (Basu et al. 2000; Maloney 2004).

Several empirical studies analyze the validity of the AWE hypothesis in the region. Martinoty (2015) uses the collapse of the Argentina's convertibility regime as a natural experiment to evaluate the effect of changes in husbands' labor situation in the labor participation decision of their wives, finding evidence of a statistically significant AWE. Similar results are found by Cerrutti (2000) and Paz (2009) also for Argentina in the 1990s and 2000s, respectively, Fernandes and Felicio (2005) for Brazil, and Parker and Skoufias (2004) for Mexico. On the other hand, McKenzie (2004) and MacKenzie (2003) find no evidence on the presence of AWE when studying household strategies to compensate the negative shocks from the financial crises of 2002 in Argentina and 1995 in Mexico, respectively.

The literature that explores the dynamics of female labor supply with aggregate level data provides more mixed results, with some papers that even report a procyclical behavior for developed countries (Tachibanaki and Sakurai 1991; Darby et al. 2001; Lee and Parasnis 2014). ${ }^{3}$

\footnotetext{
${ }^{3}$ Regarding this issue, there is a variety of recent literature, both theoretical and empirical, which tries to reconcile the differences between estimates of elasticities of female labor supply with respect to wages, based on micro data or aggregate data. For instance, Attanasio et al. (2015) estimate a life-cycle model to explain female labor supply in the United States, trying to bridge the discrepancies between micro and macro estimates. Among other results, they find that the aggregate elasticities of labor supply vary throughout the economic cycle, being stronger during recessions.
}

In contrast, in their study for Latin American countries between 1965 and 1987, Cox Edwards and Roberts (1994) show that the AWE is significant for low-income countries, although not for richer countries, such as Argentina or Chile. In a more recent work, Bhalotra and Umaña-Aponte (2010) use a panel data set for 63 developing countries for the period 1986-2006, and find that the relationship between female employment and growth is negative on average for Latin America and Asia, but positive for Africa. We improve the empirical strategy of these earlier studies by using more disaggregated and better-quality data (more Latin American countries, with longer and more comparable time series), by including more controls, and by focusing directly on female labor force participation instead of the employment rate.

In this paper we deepen the analysis of the main hypothesis in Gasparini and Marchionni (2017): the deceleration of the growth rate of female labor supply could be related to the strong economic expansion experienced by the Latin American countries in the 2000s. The better economic scenario, which resulted in an improved labor situation especially for the less skilled male workers, could have encouraged an inverse addedworker effect on their female partners. In other words, women, especially the most vulnerable, may have decided to postpone their entry into the labor market due to a lower pressure to search for a job. This paper overcomes some methodological limitations and at the same time deviates in some directions from the analysis in Gasparini and Marchionni (2017), besides extending the period of analysis. Their estimations are based on cross-country panel data and include as unique regressors the cyclical and trend components of GDP. Instead, in this paper we estimate multivariate models combining variables associated with the macroeconomic context (the abovementioned trend and cycle components of GDP) with others related to demographic characteristics and public policies. Among the regressors, we include the coverage of conditional cash transfer programs, proxied by the proportion of beneficiaries in the population. In addition, we build a panel dataset disaggregating the adult population into groups defined by education and age for each country, which significantly increases the cross-section variability. In this way, our models allow for a better identification of the partial correlations between labor force participation and each of its covariates, as we control for fixed effects by country and by population group, among other variables.

\section{Data sources}

Our analysis is mostly based on microdata from household surveys, which are part of the Socioeconomic Database for Latin America and the Caribbean (SEDLAC), 
a project jointly developed by CEDLAS at Universidad Nacional de La Plata and the World Bank. Household surveys are not homogeneous across countries and in some cases not even for the same country over time. Given such heterogeneity, careful survey processing is necessary to ensure as much comparability as possible of estimates among countries and years. This is precisely one of the advantages of using the SEDLAC database, where microdata are harmonized using similar definitions of variables for each country/year and a consistent and documented protocol (see SEDLAC 2014). In this paper, we use SEDLAC microdata of 18 countries (the 17 countries in continental Latin America and the Dominican Republic). ${ }^{4}$ Table 8 in the Appendix describes the corresponding surveys and the years they cover.

Our econometric estimations are based both on a nonbalanced panel dataset of those 18 countries over the period 1987-2014, and on a more disaggregated panel dataset that follows 9 groups of women defined according to their age and education for each one of the 18 countries. However, to compute the descriptive statistics that we show in Sect. 4, we use a smaller sample of only 15 countries for the shorter 1992-2014 period. ${ }^{5}$ With this restricted sample we build a balanced panel using linear interpolations and extrapolations, for which we take information from the most proximate surveys. Table 9 in the Appendix presents a schematic summary of the composition of both the non-balanced and balanced panels.

All the statistics at the country or population-group level are computed using the corresponding sample weights. However, in order to describe the situation for the whole region we use simple averages across countries instead of population-weighted averages, to avoid that highly populated countries, such as Brazil and Mexico, drive the results. The demographic, social and labor variables are obtained from the SEDLAC microdata. The rest of the variables, such as per capita GDP, some institutional and political variables, or the coverage of social programs are taken from alternative sources (e.g. the World Development Indicators from the World Bank, or CEPALSTAT). Table 10 lists the variables used throughout the study, their definitions and the corresponding sources.

An additional clarification before moving on to the next section: following the literature on labor supply, our analysis focuses on prime-age people. In our case, we

\footnotetext{
$\overline{{ }^{4} \text { Most of the household surveys included in the sample are representative }}$ at the national level. The exceptions are Uruguay before 2006 and Argentina, where surveys cover only the urban population, which, however, represents more than $85 \%$ of the total population.

${ }^{5}$ This group excludes Dominican Republic, Colombia and Guatemala, for which there are no comparable national household surveys previous to year 2000 .
}

restrict the sample to adults between 25 and 54 years old. Labor behavior of younger individuals is more related to education decisions while the labor supply of older people mostly depends on the relevance and dynamics of the pension system.

\section{The economic cycle and female labor force participation in Latin America}

The deceleration since the early 2000s, after a strong increase during the previous decades, has been a major change in the dynamics of female labor supply in Latin America. ${ }^{6}$ Figure 1 shows that the deceleration is robust to the group of countries chosen. ${ }^{7}$ While the growth of female LFP was on average 0.91 percentage points a year between 1992 and 2002, it slowed down to 0.35 points a year between 2002 and 2014. Even though the contrast between the growth rates in both periods is not similar in all Latin American countries, it is significant in most of them and sufficiently widespread to be visible in the regional average. ${ }^{8}$ In some cases there are even signs of stagnation (Fig. 5 in the Appendix). Unlike women's, men's labor supply is much higher and more stable over time. Thus, the recent deceleration in the growth rate of female LFP delays the closing of the gender gap in labor participation. ${ }^{9}$

Gasparini and Marchionni $(2015,2017)$ show that the deceleration was stronger for women that are in more vulnerable conditions, especially those with low education, living in rural areas, and who are married and with children. Vulnerable women usually have a weaker attachment to the labor market, and thus they are more prone to enter and exit the labor market depending on the economic situation inside and outside their households. The fact that the deceleration in female LFP since the early 2000s was especially intense among vulnerable women suggests that changes in the macroeconomic context could have played an important role.

\footnotetext{
${ }^{6}$ Female labor supply strongly and persistently expanded since the $1960 \mathrm{~s}$ in Latin America (Chioda, 2011).

7 The slowdown is also evident when grouping the countries by sub-region (South and Central America) or by their initial levels of female LFP.

8 Argentina, Bolivia, Brazil, Chile, Costa Rica, Ecuador, Honduras, México, Panama, Paraguay and Venezuela experience a deceleration in the growth rate in female LFP since the decade of the 2000s.

9 We focus on labor force participation since most of the action seems to have taken place in that margin. Gasparini and Marchionni (2015) find that "Changes in hours of work for female workers were not large, not very different between decades, and not significantly different from those of males. Likewise, changes in unemployment seem to have been small and with no significant gender differences. These patterns reinforce the claim that the dynamics of labor force participation are among the most noticeable labor phenomena with a clear gender dimension over the last decades." Chioda (2011) and World Bank (2012), among others, share this conclusion.
} 


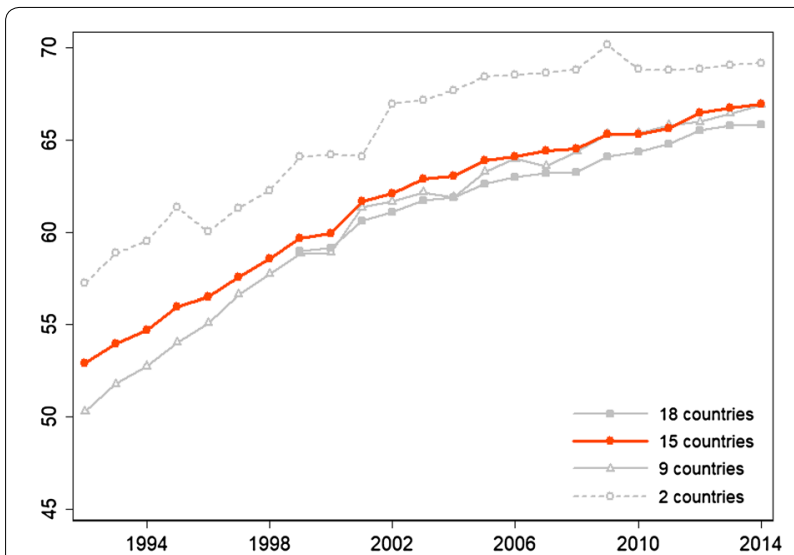

Fig. 1 Female labor force participation in Latin America. Source: own calculations based on microdata from national household surveys. Women aged 25-54. Unweighted means of Latin American countries. The series of 2 countries includes Argentina and Brazil. The series of 9 countries adds to the previous Bolivia, Chile, Costa Rica, Honduras, Mexico, Uruguay, and Venezuela. The series of 15 countries adds to the previous Ecuador, El Salvador, Nicaragua, Panama, Paraguay, and Peru. The series of 18 countries includes the previous 15 countries plus Colombia, Guatemala, and the Dominican Republic

In fact, the macroeconomic conditions in Latin America were significantly different in the 2000s compared to the previous decade. While the average GDP grew at an annual rate of $1.9 \%$ between 1990 and 1999, it grew 3.5\% per year on average between 2000 and 2014, despite the effects of the 2008 global financial crisis. In addition to the higher growth rates, the 2000s were characterized by more macroeconomic stability than previous decades.

Figure 2 shows that the strong increase in per capita GDP in the region over the 2000s occurred in coincidence with the deceleration of female LFP. ${ }^{10}$ As discussed in Sect. 2, the effect of economic growth on women's labor supply could be either positive or negative depending on whether it is the substitution or the income effect that prevails. On the one hand, an improved macroeconomic context can encourage female LFP through a substitution effect, but on the other hand it can depress female labor supply because the better economic situation in the household alleviates the pressure on women to look for a job outside the house, allowing them to postpone their entry into the labor market.

As above mentioned, the latter argument is a variant of the hypothesis of the added-worker effect (AWE), generally used to explain the increase in female LFP in response to unemployment shocks and the drop in family income during economic recessions. Conversely, as

\footnotetext{
${ }^{10}$ Figure 6 in the Appendix shows the GDP per capita series for each one of the countries under analysis.
}

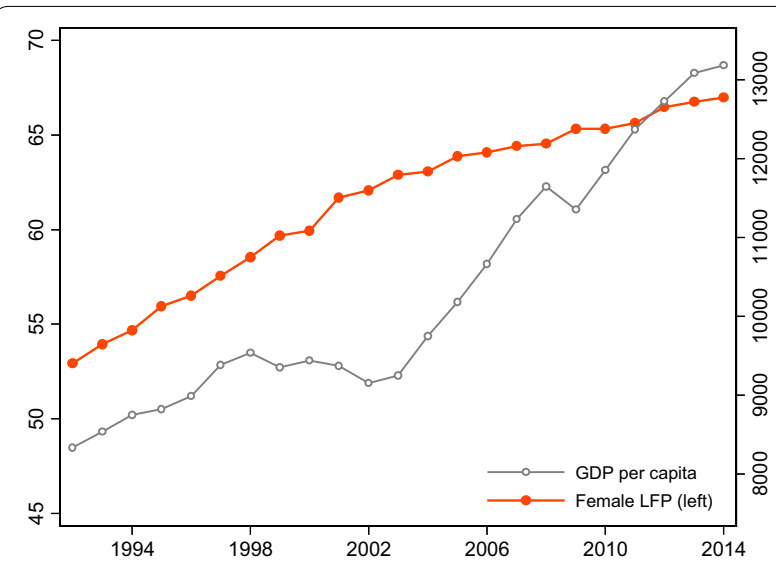

Fig. 2 Female labor force participation and economic growth. Source: own calculations based on microdata from national household surveys, per capita GDP (in PPP-adjusted constant US\$) from WDI. Women aged 25-54. Unweighted means of 15 Latin American countries

labor conditions for the primary workers improve during a period of strong economic expansion, female secondary workers could feel discouraged from participating in the labor market. The incentives for women do not necessarily imply an exit from the labor market, but a postponement of the decision to enter the market, for instance, to allocate more time caring for their children or the elderly at home. Also, the better economic conditions inside and outside the household can relieve the pressure on women acting as secondary workers to take any kind of job, allowing them to wait until they find a job that fits their preferences.

Therefore, if the AWE outweighs the substitution effect, female LFP should exhibit a countercyclical behavior. In this sense, it is important to notice that the AWE should be much more relevant for women from more vulnerable households. In fact, as discussed above, poor women, with low educational attainment and with young children are more likely to act as secondary workers, as they have a weaker attachment to the labor market and their labor decisions are more sensitive to the economic situation in their households (Michalopoulos et al. 1992; Kimmel 1998; Eissa and Hoynes 2004; Naz 2004; Tamm 2009). It is precisely these women who have benefitted most from the economic expansion in the 2000s, through improvements in the employment rate and earnings of men in their families.

Figure 3 illustrates this point by showing the evolution of some labor variables for high-skilled relative to low-skilled prime-age men. The hourly wage ratio between men with high and low education has substantially shrunk since the early 2000s. This fact suggests that in addition to the generalized increase in real wages, the 


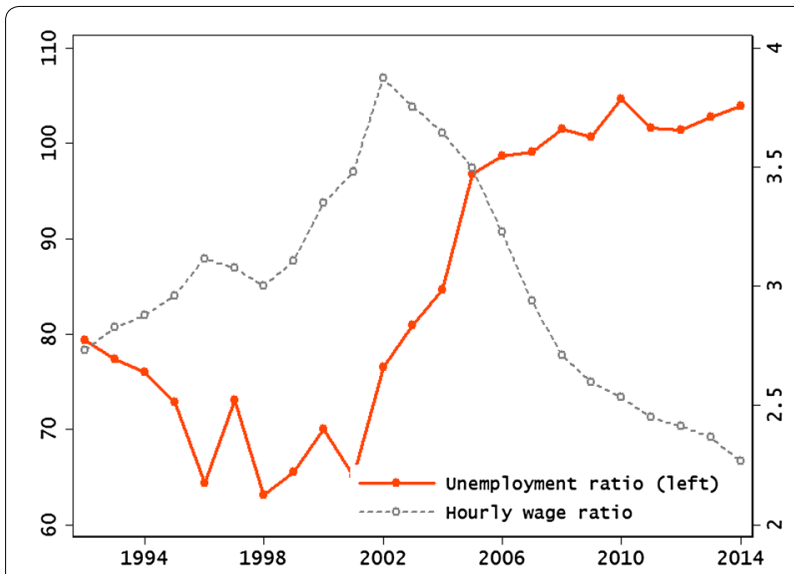

Fig. 3 Unemployment and hourly wage ratios between men with high and low education. Men aged 25-54. Source: own calculations based on microdata from national household surveys. Note: the ratios are defined as high education/low education, where low education = less than secondary complete, high education = tertiary complete. Unweighted means of 15 Latin American countries

economic improvement was greater in poor than in nonpoor households. Also, there has been a pronounced decline in the unemployment rate of unskilled men, which fell from $6.1 \%$ in 2002 to $3.7 \%$ in 2014, in contrast with a more stable behavior of the unemployment rate for the skilled men, which fluctuated around $4 \%$. Figure 3 then highlights the existence of a potentially relevant added-worker effect especially for more vulnerable women who, given the positive assortative mating, are the ones likely married to low- education workers.

An additional factor that could explain the deceleration in female LFP is the income effect due to an increase in public transfers to families, especially from conditional cash transfer programs (CCTs), which have strongly expanded in Latin America since the early 2000s both in terms of number of beneficiaries and amounts transferred. Figure 4a shows that the coverage of CCTs in the region, measured as the percentage of the total population that are beneficiaries of these programs, grew from 2.7 to $18 \%$ between 2002 and 2010, and remained fairly stable over the following years. CCTs consist of transfers to poor families with children. The transfers are usually monetary and conditional on households investing in children's human capital (education, health, and nutrition). Currently, almost all the countries in Latin America have some kind of conditional cash transfer program, reaching a large fraction of the poor population. For instance, according to Stampini and Tornarolli (2012)

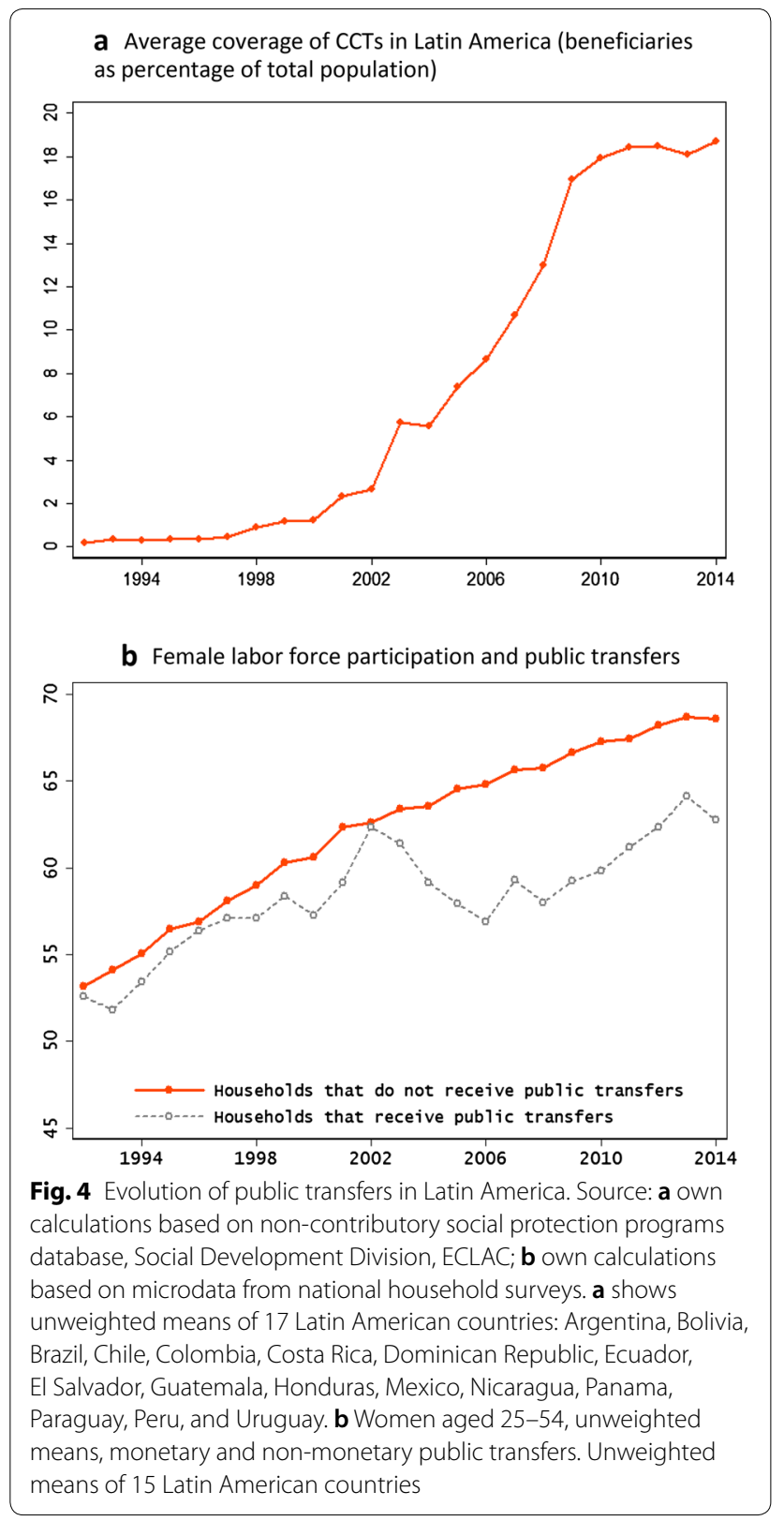

CCTs in Mexico, Brazil and Colombia cover around 50\% of the poor, while coverage in Uruguay reaches $80 \% .{ }^{11}$

The potential effects of CCTs on female LFP are ambiguous. On the one hand, there may be a negative effect operating through three different channels. For women who had the urgency to get a job due to the difficult economic situation in their homes, CCTs can provide the

\footnotetext{
$\overline{{ }^{11} \text { CCTs programs are not the only policy tool for poverty alleviation. For }}$ instance, non-contributory pensions have strongly expanded in the region during the 2000s, adding another source of non-labor income for the more vulnerable households.
} 
economic relief that allows them to delay their entrance into the labor market. Moreover, since women are typically the recipients of the cash transfer, they may perceive the subsidy as earned income in exchange for their efforts to ensure compliance with the conditionalities associated with the program, which reduces their available time to engage in market activities while encouraging the traditional division of gender roles within the household (Garganta et al. 2017). Finally, the beneficiaries of CCTs may believe that in order to continue to be eligible for the program, they should work less to remain poor. All these three channels would involve a negative effect of CCTs on female LFP. On the other hand, CCTs may have positive effects on female LFP. If conditionalities require that children go to school, they may induce women to allocate more time to market activities as they do not need to use it for childcare anymore. This could also imply that children have less time to work, which could reduce household income and increase the demand for earned income inside the family (Busso and Romero Fonseca 2015).

Figure 4b shows the evolution of labor participation of women according to whether their households receive or not public transfers, which include CCTs and other non-contributive pensions, either monetary or in kind, and exclude retirement pensions. While labor force participation rates are similar for the two groups of women over the 1990s, since the early 2000s a gap develops due to a decline in labor supply of women from beneficiary families. This fact is consistent with the hypothesis of the negative income effect discussed above. According to the meta-analysis carried out in Busso and Romero Fonseca (2015), CCTs generally have a negative effect on female LFP and hours worked, even though several studies for countries in the region find the effect to be not statistically significant.

We have argued that there are several factors that could explain the deceleration in female LFP in Latin America, and it seems that one of the most important is related to the economic cycle, even though the evidence presented so far is merely descriptive. The relationships described could be economically irrelevant or not statistically significant. Therefore, in the following sections we deepen into the analysis of the role of the economic cycle on women's labor participation decisions to assess the extent to which macroeconomic conditions can account for the recent slowdown in the rate of growth of women's labor supply in the region.

\section{Empirical strategy}

In order to study the dynamics of women's LFP over the economic cycle, we use a set of panel data models that allows us to control for some potential sources of bias. We start with the simple models in Eqs. (1) and (2), based on an unbalanced panel of 18 Latin American countries over the period 1987-2014.

$$
\begin{aligned}
& Y_{c t}=\alpha+\beta \ln (G D P p c)_{c t}+\eta_{c}+\mu_{c t} \\
& Y_{c t}=\alpha+\beta_{1} \text { cycle }_{c t}+\beta_{2} \text { trend }_{c t}+\eta_{c}+\mu_{c t}
\end{aligned}
$$

where the left-hand-side variable $Y_{c t}$ is the LFP rate for women aged 25 to 54 for country $c$ at year $t$. In model (1) we include in the right-hand side the logarithm of the real per capita GDP, while in model (2) we use its cyclical and trend components, estimated through the HodrickPrescott filter. The country fixed effects $\eta_{c}$ capture both observable and unobservable factors that vary across countries but that are fixed over time, avoiding potential sources of omitted-variable bias. ${ }^{12}$

As for other covariates of LFP, it is difficult to identify statistically significant relationships given the small number of countries and the limited variability that many social and economic indicators exhibit over time. To gain more sample variability we build a new panel with data at the population-group level, where the groups are the result of combining three levels of educational attainment (low, medium and high) and three age ranges (25-34, 35-44, and 45-54). This latter panel then follows these nine population groups of women in each of the 18 countries over the period 1987-2014. Based on the population-group level panel, we propose the specification in model (3):

$$
\begin{aligned}
Y_{g c t}= & \alpha+\beta_{1} \text { cycle }_{c t}+\beta_{2} \text { trend }_{c t}+\beta_{3} u m_{g c t} \\
& +\beta_{4} c c t_{c t}+\varphi X_{c t}+\theta Q_{g c t}+\eta_{c}+v_{g}+\mu_{g c t}
\end{aligned}
$$

The left-hand-side variable $Y_{g c t}$ is the LFP rate for women in group $g$ for country $c$ at year $t$. As in models (1) and (2), the right-hand side includes the cyclical and trend components of per capita GDP for each country and year. To assess the relevance of the added-worker effect we include the male unemployment rate of group $g$ in country $c$ of year $t\left(u m_{g c t}\right)$ as an additional explanatory variable. If the hypothesis of the inverse added-worker effect is valid, we expect that as we add this factor, the absolute value of the estimated coefficient of the cyclical component of per capita GDP decreases. Also, in order to evaluate the relationship between the conditional cash transfer programs and the changes in female LFP, we include the coverage of such programs for each country and year $\left(c c t_{c t}\right) . X_{c t}$ are other controls that vary across countries and through time, such as the share of the value added of the service sector in the GDP and the share of rural

\footnotetext{
${ }^{12}$ Our basic specification does not control for year fixed effects, but we perform some robustness checks where we do, finding that the main results hold See the discussion at the end of Sect. 6.2 and Table 6. Since GDP varies by country and by year, it is not possible to control for year fixed effects separately for each country.
} 
population, and $Q_{g c t}$ are covariates that also vary across the groups $g$, such as education, fertility, marital status, age of children, average wage of women, and gender wage gap. Tables 10 and 11 in the Appendix provide definitions and descriptive statistics of the variables. $\eta_{c}$ and $v_{g}$ are fixed effects by country and by group, respectively.

We estimate models (1), (2) and (3) for women, men, and the gender ratio (men/women), in order to explore differences in the effect of the economic cycle by gender. The estimation results are presented and discussed in Sect. 6 .

Although in model (3) we control for a quite large set of potentially relevant factors, including the unobserved heterogeneity that varies across countries or across groups but is fixed over time, it may still be insufficient and other potential sources of bias may persist. For instance, measurement error in the cyclical component of GDP per capita could lead to attenuation bias of our estimator of $\beta_{1}$. However, as we will see in the next section, all our results indicate a strong and statistically significant countercyclical behavior of female LFP. In any case, we carried out robustness checks to other alternative measures of the cyclical and trend components and the results hold. ${ }^{13}$ Also, the reciprocal relationship between the business cycle and female LFP may bias our OLS estimates towards zero. This would be the case if, for instance, female LFP positively affects economic growth (Tsani et al. 2013; Elborgh-Woytek et al. 2013). We address the concerns regarding this potential source of endogeneity by applying an instrumental variables strategy to identify the causal effect of the cyclical component of GDP on female LFP. We propose to use exports prices as instruments for the cyclical component. ${ }^{14}$ The validity of this instrument is discussed in the next section. For the estimation, we use the two-stage least squares (2SLS) procedure, considering the cyclical and trend components as endogenous variables.

\section{Results}

In this section we present the main results of our analysis. We start by discussing the models at the country level, then expand the analysis to a panel at the countrygroup level and we end by providing instrumental variables estimates to reinforce the credibility of our results.

\footnotetext{
${ }^{13}$ For the Hodrick-Prescott filter we use a smoothing parameter of 100 (Hodrick and Prescott 1997). We checked the sensitivity of our results to changes in the smoothing parameter of the Hodrick-Prescott filter and to the use of three other filters: the Baxter-King band pass filter (Baxter and King 1999), the band pass filter (Christiano and Fitzgerald 2003) and a Butterworth filter (Gómez 2001). In all cases, our results hold, i.e., we find a countercycli$\mathrm{cal}$ and statistically significant behavior of female labor participation. Results available upon request.

${ }^{14}$ We are thankful to one referee for suggesting the use of this instrument.
}

\subsection{Analysis at the country level}

We start with the simple models at the country level in Eqs. (1) and (2), as in Gasparini and Marchionni (2017). Table 1 shows the OLS estimation results of country fixed effects models of labor force participation based on an unbalanced panel of 18 Latin American countries in the 1987-2014 period. The dependent variables are female LFP (columns 1 and 2), male LFP (columns 3 and 4), and the gender ratio in LFP (men to women, in percentage, in columns 5 and 6 ). As explanatory variables we include the logarithm of real per capita GDP, and alternatively its cyclical and trend components.

The results in Table 1 suggest that changes in GDP are positively related to female LFP: a 10 percent increase in per capita GDP is associated with an increase in female LFP of 2.26 percentage points (pp.) on average. When decomposing per capita GDP, we find a statistically significant relationship both with the cyclical and the trend components, but with opposite signs. Whereas the trend component is associated with an increase in female LFP (2.56 pp.), the short-term movements are countercyclical: a 10 percent increase in the cyclical component of the GDP is associated with a reduction in female LFP of approximately $2.17 \mathrm{pp}^{15}$ This latter result is consistent with the hypothesis that the unusual strong economic growth experienced by many Latin American countries during the 2000s contributed to the deceleration in women's labor supply. In fact, a back-to-the-envelopecalculation with the results from Table 1 suggests that the cyclical component of the GDP growth of the Latin American economies over the 2000s may account for $43 \%$ of the deceleration in female LFP.

In contrast with the case of women, changes in per capita GDP or its cyclical and trend components are not associated with male labor supply, which shows very little variation over the period under study. As a consequence, the labor force participation gap between men and women is negatively correlated with the GDP trend, but positively correlated with the cyclical component. ${ }^{16}$ In sum, the estimation results from models in Eqs. (1) and (2) indicate that female LFP increases with economic

\footnotetext{
${ }^{15}$ Our results are consistent with those of Bhalotra and Umaña-Aponte (2010), who find a countercyclical pattern of female LFP in Latin America and Asia.

${ }^{16}$ Using a similar regression framework, we find that the employment rate is also positively related to the GDP per capita growth for women but not for men. The effect of the trend component is positive and particularly strong for women, while the cycle is especially strong for males. In addition, unemployment is negatively related to GDP, and the effects of both cycli$\mathrm{cal}$ and trend components are negative and statistically significant for both genders. In turn, wages increase as GDP expands for both men and women. An increase in the trend component of per capita GDP is associated with reductions in the gender wage gap, while short-term expansions widen it. These results are available upon request.
} 
Table 1 Models of labor force participation

\begin{tabular}{|c|c|c|c|c|c|c|}
\hline & \multicolumn{2}{|l|}{ Women } & \multicolumn{2}{|l|}{ Men } & \multicolumn{2}{|c|}{ Ratio men/women } \\
\hline & (1) & (2) & (3) & (4) & (5) & (6) \\
\hline Log GDP per capita & $\begin{array}{l}22.6^{* * *} \\
(2.79)\end{array}$ & & $\begin{array}{l}-1.1 \\
(0.87)\end{array}$ & & $\begin{array}{l}-73.0^{* * *} \\
(14.41)\end{array}$ & \\
\hline Cyclical component & & $\begin{array}{l}-21.7^{* * *} \\
(6.05)\end{array}$ & & $\begin{array}{l}2.3 \\
(1.58)\end{array}$ & & $\begin{array}{l}61.9^{* * *} \\
(16.25)\end{array}$ \\
\hline Trend component & & $\begin{array}{l}25.6^{* * *} \\
(2.86)\end{array}$ & & $\begin{array}{l}-1.3 \\
(0.93)\end{array}$ & & $\begin{array}{l}-82.2^{* * *} \\
(14.83)\end{array}$ \\
\hline Observations & 304 & 304 & 304 & 304 & 304 & 304 \\
\hline Countries & 18 & 18 & 18 & 18 & 18 & 18 \\
\hline R-squared & 0.56 & 0.66 & 0.04 & 0.06 & 0.49 & 0.57 \\
\hline
\end{tabular}

Latin American countries, panel 1987-2014. Adults aged 25-54

Fixed effects (by country) OLS regressions. Unbalanced panel of 18 countries. Dependent variable: in columns 1 and 2 ( 3 and 4 ) is female (male) labor force participation as percentage of women (men) aged 25-54; in columns 5 and 6 is the LFP ratio (men/women) expressed in percentage. Log per capita GDP is the logarithm of real gross domestic product per capita. Cyclical and trend components of GDP are obtained by applying the Hodrick-Prescott filter to the log of per capita GDP. For detailed data definitions and sources, see Table 10 in the Appendix. Robust standard errors clustered by country in parentheses. ${ }^{* *}$ Significant at $1 \%$ level, ${ }^{*} 5 \%,{ }^{*} 10 \%$

development, reducing the gender gap in labor supply; however, short-term economic expansions are associated with a decline in the entry of women into the labor force, and thus with a widening of the gender gap.

We already suggested that an inverse added-worker effect (AWE) could be the mechanism behind these results. Although we cannot provide causal evidence with the data at hand, we can explore whether some predictions of this hypothesis are consistent with the evidence. In what follows we explore two implications of the inverse AWE argument. First, since the mechanism operates through adjustments within the household, the results should differ across women from different household arrangements. ${ }^{17}$ In particular, we expect the sensitivity of LFP to cyclical fluctuations of GDP to be higher for women living with her spouse and with young children, since, as argued above, they are more likely to act as secondary workers within the household. The results in Table 2 are consistent with this expectation. The coefficient for the cyclical component of GDP is higher (in absolute value) for women living with a spouse ("married"); in fact, the coefficient is negative but statistically non-significant for the group of single women. Accordingly, the ratio in LFP between married and single women falls (i.e. the gap in LFP between these groups becomes larger) as the cyclical component of the GDP increases (column 3).

When classifying women by their family structure (columns 4 to 8 ), the negative effect of the cyclical component of the GDP is significant only for women in two-parent families. The effect vanishes for women in single-parent

\footnotetext{
${ }^{17}$ We are thankful to one referee for making this observation.
}

families or for women living alone. ${ }^{18}$ Finally, the results in columns 9 to 13 suggest that women with young children are more prone to react to improved economic conditions than those with older children or no children at all, a result again consistent with the inverse-AWE story.

As discussed in Sect. 4, another implication of the AWE argument is that we should observe a stronger reaction to the cyclical movements in economic activity for the group of more socioeconomic vulnerable women. To this aim we estimate the female LFP models by education, household size, per capita family income, marital status, area of residence, and family types. We also build a vulnerability index based on the principal components of these variables. According to this index, vulnerable individuals are those with a very low educational attainment, living in rural areas, with many children, and with low incomes. Table 3 shows the estimation results of model (2) by educational group, and for the vulnerable and nonvulnerable population, defined as quintiles 1 and 5 of the vulnerability index, respectively. ${ }^{19}$

According to our results, the negative relationship between the cyclical component of per capita GDP and female LFP is stronger for less educated, more vulnerable women. Whereas the coefficient associated with

\footnotetext{
${ }^{18}$ We also divide women into "head of household" and other members. We use two alternative definitions for "head of household": (i) status self-reported in the survey, or (ii) family member with the highest earnings (economic definition). In both cases the coefficient of the cyclical component is much higher (in absolute value) for group of women who are not heads of household. In fact, in the economic definition the coefficient is non-significant for female household heads.

19 The results for other population groups are consistent with those presented in Table 3 and are available upon request.
} 
Table 2 Models of female labor force participation by household structure

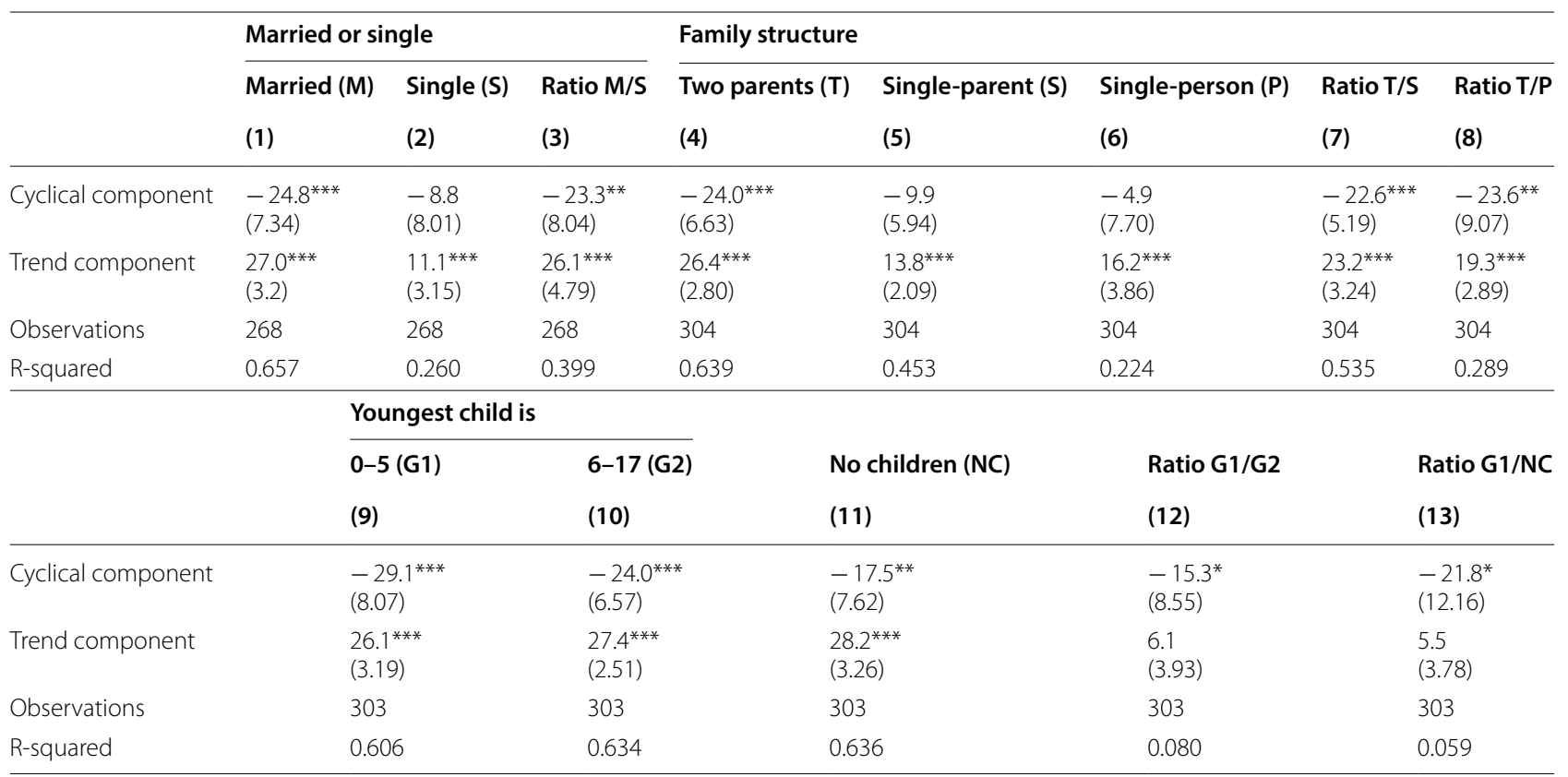

Latin American countries, panel 1987-2014. Women aged 25-54

Fixed effects (by country) OLS regressions. Unbalanced panel of 18 countries. Dependent variable: female labor force participation as percentage of women aged 25-54; and ratios of female LFP ratio between groups expressed in percentage. Cyclical and trend components of GDP are obtained by applying the HodrickPrescott filter to the log of real per capita GDP. For detailed data definitions and sources, see Table 10 in the Appendix. Robust standard errors clustered by country in parentheses. ${ }^{* * *}$ Significant at $1 \%$ level, ${ }^{* *} 5 \%,{ }^{*} 10 \%$

the cyclical component is -23.6 for the group of women with less than complete secondary schooling, it halves $(-11.3)$ for women with a degree from a tertiary institution. In fact, that coefficient is negative and significant in a regression for the ratio of LFP between low and higheducated women, suggesting a widening gap between these groups over the expansive phase of the business cycle. Columns 6 to 8 report the results for the vulnerability groups defined above. Whereas the coefficient associated with the cyclical component is negative $(-9.0)$ but not statistically significant for non-vulnerable women (top quintile of the vulnerability index), the coefficient for the most vulnerable group is much larger in absolute value $(-26.0)$ and highly significant.

Unlike the results in Table 3, male labor supply does not seem to move in line with changes in per capita GDP: the coefficients of the LFP regressions are much smaller for men and non-statistically significant in most cases. ${ }^{20}$ Accordingly, the labor force participation ratio between men and women is positively related to the cyclical component of per capita GDP and negatively related to the

\footnotetext{
${ }^{20}$ The results for men and for the ratio men/women (not reported) are available upon request.
}

trend component, particularly for the more vulnerable/ less educated groups.

\subsection{Analysis at the country-group level}

In order to gain more sample variability, we estimate model (3) based on a more disaggregated panel dataset where the units of observation are population groups defined in terms of schooling and age for each country and year. This also allows us to include other potential drivers of female LFP, besides the cyclical and trend components of GDP, such as the male unemployment rate and the coverage of CCT programs. We also control for other potential covariates of female LFP: factors that are jointly determined with the labor supply decisions (education, marriage, fertility), and factors that are likely exogenous to the individuals (gender income gap, cost of childcare and eldercare services, women's income, share of the services sector in GDP, rural population). ${ }^{21,22}$

\footnotetext{
${ }^{21}$ It should be noted that including women's wages and a proxy of the importance of the services sector contributes to controlling for factors related to the labor demand, which in turn are correlated with the business cycle. Therefore, these controls would likely capture the fact that recessions or short-term economic expansions can generate compositional changes in the productive structure, thus affecting female LFP.

22 The correlations of each of these additional controls with female LFP have the expected signs according to the empirical literature (see Busso and Romero Fonseca 2015).
} 
Table 3 Models of female labor force participation by educational attainment and vulnerability

\begin{tabular}{|c|c|c|c|c|c|c|c|c|}
\hline & \multicolumn{5}{|l|}{ Education } & \multicolumn{3}{|l|}{ Vulnerability } \\
\hline & $\begin{array}{l}\text { Low (L) } \\
\text { (1) }\end{array}$ & $\begin{array}{l}\text { Medium (M) } \\
\text { (2) }\end{array}$ & $\begin{array}{l}\text { High (H) } \\
(3)\end{array}$ & $\begin{array}{l}\text { Ratio L/M } \\
\text { (4) }\end{array}$ & $\begin{array}{l}\text { Ratio L/H } \\
\text { (5) }\end{array}$ & $\begin{array}{l}\text { Vulnerable (V) } \\
\text { (6) }\end{array}$ & $\begin{array}{l}\text { Non-vulnerable (N) } \\
\text { (7) }\end{array}$ & $\begin{array}{l}\text { Ratio V/N } \\
\text { (8) }\end{array}$ \\
\hline Cyclical component & $\begin{array}{l}-23.6^{* * *} \\
(7.12)\end{array}$ & $\begin{array}{l}-16.9^{* *} \\
(7.33)\end{array}$ & $\begin{array}{l}-11.3^{* * *} \\
(3.30)\end{array}$ & $\begin{array}{l}-15.5^{* * *} \\
(5.16)\end{array}$ & $\begin{array}{l}-19.9^{* *} \\
(7.29)\end{array}$ & $\begin{array}{l}-26.0^{* * *} \\
(7.97)\end{array}$ & $\begin{array}{l}-9.0 \\
(6.04)\end{array}$ & $\begin{array}{l}-22.4^{*} \\
(10.67)\end{array}$ \\
\hline Trend component & $\begin{array}{l}22.1^{* * *} \\
(2.63)\end{array}$ & $\begin{array}{l}10.3^{* * *} \\
(3.51)\end{array}$ & $\begin{array}{l}10.1^{* * *} \\
(2.94)\end{array}$ & $\begin{array}{l}20.8^{* * *} \\
(4.43)\end{array}$ & $\begin{array}{l}18.9^{* * *} \\
(2.73)\end{array}$ & $\begin{array}{l}29.1^{* * *} \\
(3.32)\end{array}$ & $\begin{array}{l}13.5^{* * *} \\
(3.14)\end{array}$ & $\begin{array}{l}29.8^{* * *} \\
(6.40)\end{array}$ \\
\hline Observations & 304 & 304 & 304 & 304 & 304 & 304 & 304 & 304 \\
\hline R-squared & 0.557 & 0.219 & 0.260 & 0.351 & 0.397 & 0.520 & 0.235 & 0.256 \\
\hline
\end{tabular}

Latin American countries, panel 1987-2014. Women aged 25-54

Fixed effects (by country) OLS regressions. Unbalanced panel of 18 countries. Dependent variable is female labor force participation as percentage of women aged 25-54. Columns show estimations of the models dividing individuals by different levels of educational attainment and quintiles of a vulnerability index; and ratios of female LFP ratio between groups expressed in percentage. Low education = less than secondary complete; medium education $=$ secondary complete or tertiary incomplete; high education = tertiary complete. Vulnerable = individuals who are in quintile 1 of a vulnerability index based on the principal components of level of educational attainment, marital status and number of children in the household. Cyclical and trend components of GDP are obtained by applying the HodrickPrescott filter to the log of real per capita GDP. For detailed data definitions and sources, see Table 10 in the Appendix. Robust standard errors clustered by country in parentheses. ${ }^{* * *}$ Significant at $1 \%$ level, ${ }^{* *} 5 \%,{ }^{*} 10 \%$

Table 4 presents the estimation results of alternative specifications of model (3) with fixed effects by country and by group. ${ }^{23}$ As a general result, we find that the sign and statistical significance of the coefficients associated with the cyclical and trend components of GDP are robust across specifications. The absolute value decreases as we incorporate additional regressors into the model. For instance, according to the basic model with controls (column 2) a 10-percent increase in the cyclical component of per capita GDP is associated with a fall in female LFP of 2.17 pp., whereas the estimated fall is reduced to $1.72 \mathrm{pp}$. when we include male unemployment, CCTs coverage and the full set of controls (column 8).

Our estimates suggest that men's unemployment rate may explain part of the countercyclical behavior of female LFP. Indeed, when the model includes that variable, the coefficient associated with the cyclical component falls significantly. The partial correlation between male unemployment and female LFP is always positive and statistically significant in the regressions with controls. When men's unemployment rate increases 1 pp., women's labor supply rises around $0.21 \mathrm{pp}$. This result is consistent with the added-worker effect and could explain part of the negative association between female LFP and the business cycle. On the other hand, the coefficients for CCTs coverage are negative in the models including controls (columns 4 and 8 ) although small in magnitude and never statistically significant. ${ }^{24}$

\footnotetext{
${ }^{23}$ The tables with the coefficients for all the variables in the regressions are available upon request.

${ }^{24}$ In part this result may be due to little variability in the data: we have data on CCTs coverage by country-year and not by group.
}

Table 5 shows the results of estimating model (3) with the labor force participation ratio between men and women as the dependent variable. Cyclical expansions are associated with a widening of the gender gap: a 10 -percent increase in per capita GDP is associated with an increase in the gender gap that ranges between $3.2 \mathrm{pp}$. and 5.8 pp. across specifications. CCTs coverage is statistically significant only in specifications that include the full set of controls. A 10-pp. increase in CCTs coverage is related to a widening of the gender ratio in labor supply of about $1.8 \mathrm{pp}$.

Table 6 reports a range of specifications of models and different estimation methods as robustness checks. For instance, we use pooled OLS, a first-difference estimator, the Arellano and Bond (1991) GMM estimator for a dynamic model, and a random-effect estimator. We also estimate model (3) adding year fixed effects to the country and group fixed effects. We add controls for educational group trends, and additional variables that refer to cultural or legal factors, although in these cases the number of observations falls. We also restrict the sample to countries with available data for more than 10 and 20 years. In all cases, the main results hold: the countercyclical behavior of female LFP seems a robust result.

Of course, we are not controlling for all possible factors affecting female LFP and then our results could be biased due to omitted variables. One of these variables could be the expansion of pre-school and child-care coverage. ${ }^{25}$ Unfortunately we were not able to build such a variable for all countries spanning over the period analyzed in the

\footnotetext{
${ }^{25}$ We are thankful to one referee for this observation.
} 
Table 4 Models of female labor force participation

\begin{tabular}{|c|c|c|c|c|c|c|c|c|}
\hline & (1) & $(2)$ & (3) & (4) & (5) & (6) & (7) & $(8)$ \\
\hline Cyclical component & $\begin{array}{l}-17.2^{* * *} \\
(5.24)\end{array}$ & $\begin{array}{l}-21.7^{* * *} \\
(5.08)\end{array}$ & $\begin{array}{l}-13.1^{* * *} \\
(4.24)\end{array}$ & $\begin{array}{l}-20.3^{* * *} \\
(5.28)\end{array}$ & $\begin{array}{l}-13.5^{* *} \\
(5.44)\end{array}$ & $\begin{array}{l}-18.2^{* * *} \\
(5.99)\end{array}$ & $\begin{array}{l}-10.1^{*} \\
(4.79)\end{array}$ & $\begin{array}{l}-17.2^{* *} \\
(6.39)\end{array}$ \\
\hline Trend component & $\begin{array}{l}15.5^{* * *} \\
(2.79)\end{array}$ & $\begin{array}{l}7.3^{* *} \\
(3.25)\end{array}$ & $\begin{array}{l}15.8^{* * *} \\
(4.17)\end{array}$ & $\begin{array}{l}10.0^{* * *} \\
(2.67)\end{array}$ & $\begin{array}{l}15.3^{* * *} \\
(2.68)\end{array}$ & $\begin{array}{l}8.6^{* *} \\
(3.27)\end{array}$ & $\begin{array}{l}15.4^{* * *} \\
(3.97)\end{array}$ & $\begin{array}{l}11.2^{* * *} \\
(2.64)\end{array}$ \\
\hline CCTs coverage & & & $\begin{array}{l}1.3 \\
(4.97)\end{array}$ & $\begin{array}{l}-2.0 \\
(3.22)\end{array}$ & & & $\begin{array}{l}1.2 \\
(4.70)\end{array}$ & $\begin{array}{l}-1.6 \\
(3.30)\end{array}$ \\
\hline Male unemployment & & & & & $\begin{array}{l}18.4 \\
(11.03)\end{array}$ & $\begin{array}{l}20.9^{* *} \\
(9.12)\end{array}$ & $\begin{array}{l}15.5 \\
(11.65)\end{array}$ & $\begin{array}{l}21.0^{* *} \\
(9.72)\end{array}$ \\
\hline Additional controls & No & Yes & No & Yes & No & Yes & No & Yes \\
\hline Observations & 2736 & 2537 & 2511 & 2321 & 2669 & 2476 & 2445 & 2261 \\
\hline R-squared & 0.837 & 0.854 & 0.831 & 0.851 & 0.845 & 0.858 & 0.839 & 0.856 \\
\hline
\end{tabular}

Latin American countries, panel of education and age groups, 1987-2014. Women aged 25-54

Fixed effects (by country and by group) OLS regressions. Unbalanced panel of 9 groups in 18 countries. Dependent variable: female labor force participation as percentage of women aged 25-54. Cyclical and trend components of GDP are obtained by applying the Hodrick-Prescott filter to the log of real per capita GDP. CCTs program coverage as share of population who are beneficiaries (not available for Venezuela). Unemployment rate for men in each education and age group. Additional controls: average years of education, average number of children, share of married women, share of women in charge of old person, average age of children in household, female hourly wage, hourly wage ratio (men/women), service sector value added as share of GDP, rural population as share of total population. For detailed data definitions and sources, see Table 10 in the Appendix. Robust standard errors clustered by country in parentheses. ${ }^{* *}$ Significant at $1 \%$ level, ${ }^{* *} \%$, *10\%

paper. However, we do not expect the inclusion of that variable to be a serious threat to our main results. For countries for which data is available, the rate of growth in pre-school coverage was either constant or increasing in the 2000s, and then it can hardly account for a deceleration in female labor force participation. ${ }^{26}$ In any case, our results also hold for women without children and with children older than 6 , who were not affected by an increase in pre-school and child-care coverage.

By all means, all the models estimated so far may potentially suffer from endogeneity bias. Although we are aware that we cannot rule out all endogeneity concerns with the data at hand, in the next section we carry out an additional robustness exercise to reinforce the credibility of our results.

\subsection{Instrumental variables}

With the aim of alleviating the concern for endogeneity we use instrumental variables and estimate model (3) through two-stage least squares (2SLS). In order to instrument the cyclical and trend components of the GDP we follow Besley and Pearson (2008), Brückner and Ciccone (2010) and McGuirk and Burke (2016), among others, and use exports prices. There is a large literature that discusses the close relationship between exports prices and the cyclical component of economic growth in Latin America (e.g. Erten and Ocampo 2013; Ocampo 2017). In particular, the large upswing in GDP over the

\footnotetext{
${ }^{26}$ In a sample of 6 countries with data from the early 1990s, the share of children aged 3 to 5 attending pre-school increased a rate of 1.1 pp per year in the $1990 \mathrm{~s}$ and $1.2 \mathrm{pp}$ in the 2000s.
}

2000s seems to have been largely attributed to improved exports prices for the region. Since Latin American economies are small, international prices can be considered exogenous and then largely unaffected by domestic variables such as LFP.

Table 7 shows the results using the exports price index for each Latin American country computed by the United Nations Conference on Trade and Development (UNCTAD) as instrumental variable for GDP. ${ }^{27}$ In all specifications, independently of whether we consider the cycle or the trend as endogenous variables, the estimated coefficient for the cyclical component of per capita GDP continues to be negative and statistically significant, although larger than the fixed effects estimates from subsection 6.2. This suggests that, if the instruments were valid, our previous results suffer from attenuation bias, so they could be interpreted as a lower bound of the true effect of the economic cycle on female LFP. ${ }^{28}$

\section{Concluding remarks}

In this paper we explore the relationship between female labor force participation and the trend and cycle components of GDP based on fixed-effect models using panel

\footnotetext{
${ }^{27}$ Prices are constructed using UNCTADstat Commodity Price Statistics, international and national sources and UNCTAD secretariat estimates.

28 Alternatively, we also used terms of trade and the international prices of the main commodities exported by each country as instruments for GDP (UNCTAD data). When using these instruments, we again find a negative and significant coefficient for the cyclical component of per capita GDP (results available upon request).
} 
Table 5 Models of relative labor force participation (male/female)

\begin{tabular}{|c|c|c|c|c|c|c|c|c|}
\hline & (1) & (2) & (3) & (4) & (5) & (6) & (7) & (8) \\
\hline Cyclical component & $\begin{array}{l}49.8^{* * *} \\
(13.90)\end{array}$ & $\begin{array}{l}58.1^{* * *} \\
(16.71)\end{array}$ & $\begin{array}{l}41.8^{* *} \\
(14.45)\end{array}$ & $\begin{array}{l}56.4^{* * *} \\
(18.86)\end{array}$ & $\begin{array}{l}32.0^{*} \\
(15.39)\end{array}$ & $\begin{array}{l}45.4^{* *} \\
(19.01)\end{array}$ & $\begin{array}{l}26.4 \\
(17.05)\end{array}$ & $\begin{array}{l}45.0^{*} \\
(21.81)\end{array}$ \\
\hline Trend component & $\begin{array}{l}-53.2^{* * *} \\
(10.63)\end{array}$ & $\begin{array}{c}-17.2 \\
(14.81)\end{array}$ & $\begin{array}{l}-58.5^{* * *} \\
(15.35)\end{array}$ & $\begin{array}{l}-28.0^{*} \\
(14.27)\end{array}$ & $\begin{array}{l}-56.7^{* * *} \\
(11.27)\end{array}$ & $\begin{array}{l}-19.3 \\
(14.59)\end{array}$ & $\begin{array}{l}-62.2^{* * *} \\
(15.79)\end{array}$ & $\begin{array}{l}-30.6^{* *} \\
(12.90)\end{array}$ \\
\hline CCTs coverage & & & $\begin{array}{l}9.9 \\
(19.36)\end{array}$ & $\begin{array}{l}17.3^{*} \\
(8.54)\end{array}$ & & & $\begin{array}{l}12.0 \\
(19.53)\end{array}$ & $\begin{array}{l}19.2^{*} \\
(9.36)\end{array}$ \\
\hline Male unemployment & & & & & $\begin{array}{l}-99.5^{* *} \\
(42.65)\end{array}$ & $\begin{array}{l}-74.8^{* *} \\
(27.72)\end{array}$ & $\begin{array}{l}-93.9^{*} \\
(44.98)\end{array}$ & $\begin{array}{l}-77.9^{* *} \\
(28.55)\end{array}$ \\
\hline Additional controls & No & Yes & No & Yes & No & Yes & No & Yes \\
\hline Observations & 2736 & 2537 & 2511 & 2321 & 2669 & 2476 & 2445 & 2261 \\
\hline R-squared & 0.719 & 0.753 & 0.714 & 0.750 & 0.728 & 0.761 & 0.723 & 0.759 \\
\hline
\end{tabular}

Latin American countries, panel of education and age groups, 1987-2014. Adults aged 25-54

Fixed effects (by country and by group) OLS regressions. Unbalanced panel of 9 groups in 18 countries. Dependent variable: labor force participation ratio (men/ women) expressed in percentage. See notes to Table 4 for more details. Robust standard errors clustered by country in parentheses. ${ }^{* *}$ Significant at $1 \%$ level, ${ }^{* *} 5 \%$, ${ }^{*} 10 \%$

Table 6 Models of female labor force participation

\begin{tabular}{|c|c|c|c|c|c|c|}
\hline & & \multicolumn{4}{|c|}{ Dependent variable } & \multirow[t]{3}{*}{ Obs. } \\
\hline & & \multicolumn{2}{|l|}{ Female LFP (\%) } & \multicolumn{2}{|c|}{ LFP ratio (men/women) } & \\
\hline & & Cyclical comp. & Trend comp. & Cyclical comp. & Trend comp. & \\
\hline (1) & Base model & $\begin{array}{l}-17.2^{* * *} \\
(5.24)\end{array}$ & $\begin{array}{l}15.5^{* * *} \\
(2.79)\end{array}$ & $\begin{array}{l}49.8^{* * *} \\
(13.90)\end{array}$ & $\begin{array}{l}-53.2^{* * *} \\
(10.63)\end{array}$ & 2736 \\
\hline (2) & Pooled OLS & $\begin{array}{l}-14.1^{*} \\
(7.46)\end{array}$ & $\begin{array}{l}-0.6 \\
(0.53)\end{array}$ & $\begin{array}{l}35.3 \\
(22.12)\end{array}$ & $\begin{array}{l}2.0 \\
(1.56)\end{array}$ & 2736 \\
\hline (3) & Differences & $\begin{array}{l}-8.4^{* *} \\
(3.70)\end{array}$ & $\begin{array}{l}-2.6 \\
(4.27)\end{array}$ & $\begin{array}{l}19.7^{*} \\
(10.92)\end{array}$ & $\begin{array}{l}12.4 \\
(12.70)\end{array}$ & 2052 \\
\hline (4) & Dynamic panel model/1 & $\begin{array}{l}-5.7^{* * *} \\
(2.16)\end{array}$ & $\begin{array}{l}0.0 \\
(0.11)\end{array}$ & $\begin{array}{l}24.8^{* * *} \\
(6.61)\end{array}$ & $\begin{array}{l}-0.0 \\
(0.31)\end{array}$ & 1773 \\
\hline (5) & Random Effects & $\begin{array}{l}-13.4^{* * *} \\
(2.60)\end{array}$ & $\begin{array}{l}6.1^{* * *} \\
(0.63)\end{array}$ & $\begin{array}{l}33.0^{* * *} \\
(7.73)\end{array}$ & $\begin{array}{l}-11.8^{* * *} \\
(1.70)\end{array}$ & 2736 \\
\hline (6) & Year fixed effects & $\begin{array}{l}-14.0^{* *} \\
(6.35)\end{array}$ & $\begin{array}{l}8.2^{*} \\
(4.38)\end{array}$ & $\begin{array}{l}39.2^{* *} \\
(17.86)\end{array}$ & $\begin{array}{l}-32.5^{*} \\
(15.68)\end{array}$ & 2736 \\
\hline (7) & $\begin{array}{l}\text { Year fixed effects + interaction } \\
\text { year and educational groups }\end{array}$ & $\begin{array}{l}-14.0^{* *} \\
(6.42)\end{array}$ & $\begin{array}{l}8.2^{*} \\
(4.42)\end{array}$ & $\begin{array}{l}39.2^{* *} \\
(18.04)\end{array}$ & $\begin{array}{l}-32.5^{*} \\
(15.84)\end{array}$ & 2736 \\
\hline (8) & Additional controls 1 & $\begin{array}{l}-21.7^{* * *} \\
(5.08)\end{array}$ & $\begin{array}{l}7.3^{* *} \\
(3.25)\end{array}$ & $\begin{array}{l}58.1^{* * *} \\
(16.71)\end{array}$ & $\begin{array}{l}-17.2 \\
(14.81)\end{array}$ & 2537 \\
\hline (9) & Additional controls 2 & $\begin{array}{l}-19.9^{* * *} \\
(4.81)\end{array}$ & $\begin{array}{l}8.7 \\
(5.23)\end{array}$ & $\begin{array}{l}42.5^{* * *} \\
(11.21)\end{array}$ & $\begin{array}{l}-21.8 \\
(15.66)\end{array}$ & 936 \\
\hline$(10)$ & Only country $>20$ periods & $\begin{array}{l}-17.5^{* *} \\
(4.97)\end{array}$ & $\begin{array}{l}19.2^{* * *} \\
(4.50)\end{array}$ & $\begin{array}{l}55.7^{* *} \\
(18.17)\end{array}$ & $\begin{array}{l}-64.9^{* *} \\
(18.23)\end{array}$ & 1224 \\
\hline$(11)$ & Only country $>10$ periods & $\begin{array}{l}-17.7^{* * *} \\
(5.28)\end{array}$ & $\begin{array}{l}15.9^{* * *} \\
(2.82)\end{array}$ & $\begin{array}{l}50.7^{* * *} \\
(14.13)\end{array}$ & $\begin{array}{l}-54.2^{* * *} \\
(10.80)\end{array}$ & 2646 \\
\hline
\end{tabular}

Latin American countries, panel of education and age groups, 1987-2014. Adults aged 25-54

(1) Base model specification is the same presented in column 1 of Table 4 for female LFP and Table 5 for the LFP ratio (men/women). (2) Pooled OLS regression with standard errors clustered by country in parentheses. (3) First difference estimator with standard errors clustered by country in parentheses. (4) Arellano and Bond (1991) GMM estimator with robust standard errors; we instrument for cycle component using a double lag. (5) Random-effect estimator with robust standard errors in parentheses. (6) Base model adding year fixed effects with standard errors clustered by country in parentheses. (7) Specification (6) + interactions between education groups and year dummies. (8) Base model specification with control variables; these results are the same presented in column 2 of Table 4 for female LFP and Table 5 for the LFP ratio. (9) Specification (8) + additional controls such as percentage of married women using modern contraceptive methods, an indicator of legal abortion, percentage of women with a washing machine, percentage of non-practicing catholic and an index of labor market regulations. (9) Base model specification restricting the sample to countries with available data for 20 years or more. (11) Base model specification restricting the sample to countries with available data for 10 years or more. ${ }^{* *}$ Significant at $1 \%$ level, ${ }^{* *} 5 \%,{ }^{*} 10 \%$ 
Table 7 Models of female labor force participation

\begin{tabular}{|c|c|c|c|c|c|c|}
\hline & \multirow{2}{*}{\multicolumn{2}{|c|}{$\mathrm{FE}$}} & \multicolumn{4}{|l|}{ 2SLS } \\
\hline & & & \multicolumn{2}{|c|}{$\begin{array}{l}\text { Cyclical component of GDP } \\
\text { endogenous }\end{array}$} & \multicolumn{2}{|c|}{$\begin{array}{l}\text { Cyclical and trend } \\
\text { components of GDP } \\
\text { endogenous }\end{array}$} \\
\hline & (1) & $(2)$ & (3) & (4) & $(5)$ & (6) \\
\hline Cyclical component of GDP per capita & $\begin{array}{l}-17.2^{* * *} \\
(5.24)\end{array}$ & $\begin{array}{l}-21.71^{* * *} \\
(5.08)\end{array}$ & $\begin{array}{l}-36.5^{* * *} \\
(11.36)\end{array}$ & $\begin{array}{l}-28.7^{* *} \\
(11.52)\end{array}$ & $\begin{array}{l}-34.1^{* *} \\
(12.67)\end{array}$ & $\begin{array}{l}-32.4^{* * *} \\
(10.88)\end{array}$ \\
\hline Trend component of GDP per capita & $\begin{array}{l}15.5^{* * *} \\
(2.79)\end{array}$ & $\begin{array}{l}7.32^{* *} \\
(3.25)\end{array}$ & $\begin{array}{l}15.9^{* * *} \\
(2.79)\end{array}$ & $\begin{array}{l}7.9^{* *} \\
(3.35)\end{array}$ & $\begin{array}{l}16.6^{* * *} \\
(2.55)\end{array}$ & $\begin{array}{l}11.8^{*} \\
(5.98)\end{array}$ \\
\hline \multicolumn{7}{|c|}{ First stage for the cyclical component of GDP per capita } \\
\hline Exports prices_cycle & & & $\begin{array}{l}0.170^{* * *} \\
(0.037)\end{array}$ & $\begin{array}{l}0.178^{* * *} \\
(0.040)\end{array}$ & $\begin{array}{l}0.168^{* * *} \\
(0.038)\end{array}$ & $\begin{array}{l}0.180^{* * *} \\
(0.040)\end{array}$ \\
\hline Exports prices-trend & & & $\begin{array}{l}-0.047^{* * *} \\
(0.013)\end{array}$ & $\begin{array}{l}-0.022^{* * *} \\
(0.007)\end{array}$ & $\begin{array}{l}-0.020^{* * * *} \\
(0.007)\end{array}$ & $\begin{array}{l}-0.010 \\
(0.008)\end{array}$ \\
\hline F test & & & 12.97 & 19.21 & 9.903 & 11.59 \\
\hline Overid. test ( $p$ value) & & & 0.481 & 0.372 & & \\
\hline Additional controls & No & Yes & No & Yes & No & Yes \\
\hline Observations & 2736 & 2537 & 2736 & 2537 & 2736 & 2537 \\
\hline
\end{tabular}

Fixed effects OLS and instrumental variables 2SLS. Latin American countries, panel of education and age groups, 1987-2014. Women aged 25-54

Robust standard errors in parentheses ${ }^{* * *} p<0.01,{ }^{* *} p<0.05,{ }^{*} p<0.1$

Columns 1 and 2 report the fixed effects (by country and by group) OLS estimates from columns 1 and 2 of Table 4 . Columns 3 to 6 report the fixed effects (by country and by group) 2SLS regression results. Unbalanced panel of 9 groups in 18 countries. Dependent variable: female labor force participation as percentage of women aged 25-54. Instrument variables: cyclical and trend components of the UNCTAD's exports price index. Over-identification test refers to the Hansen J statistic, where the joint null hypothesis is that the instruments are valid. See notes to Table 4 for more details. Robust standard errors clustered by country in parentheses. ${ }^{* * *}$ Significant at $1 \%$ level, **5\%, ${ }^{*} 10 \%$

data from harmonized national household surveys for all Latin American countries. We find that female LFP is positively related to the trend component of per capita GDP-long-term effect-and negatively related to the cyclical component-mostly related to short-term shocks. This latter link is stronger for vulnerable women, with low educational attainment, married, with young children, and in low-income households, which is consistent with an inverse added-worker effect. We believe these results may shed light on an intriguing fact: the significant deceleration in female LFP in Latin America in the 2000s, a decade of exceptionally high economic growth.

Our results have nuanced implications in terms of wellbeing. On the one hand, the deceleration in female LFP may reflect the fact that in a more favorable economic context some women are no longer bound to enter the labor market to take precarious low-quality jobs. However, as suggested by Gasparini and Marchionni (2017), staying out of the labor market during some time could imply a loss of productivity, making women less likely to work in the future, regardless of the macroeconomic conditions. Furthermore, it could mean a strengthening of the traditional gender roles in the household, negatively affecting the perspectives of women to participate in the labor force in the long term.

\section{Acknowledgements}

This paper is based on the research that the authors carried out within the project" "Medición de las diferencias de género en las habilidades, las limitaciones de la familia y las preferencias de carrera", Gender and Diversity Division, Inter-American Development Bank. It is also a follow up of Joaquín Serrano's dissertation at the Master's Program in Economics at Universidad Nacional de La Plata, in turn based on evidence from a recent book edited by two of the authors (Gasparini and Marchionni, 2015) with the support of IDRC-Canada. We are grateful to Andrew Morrison, Monserrat Bustelo, Claudia Piras, Luana Ozemela, Guillermo Cruces, Matías Busso, Carlos Lamarche, Lorena Garegnani, Inés Berniell, seminar participants at AAEP (2016), Network of Inequality and Poverty (UNGS, 2014), IDB (Washington-DC, 2015), LACEA (2017), and to the editor of the journal and two anonymous referees for valuable comments and suggestions. 


\section{Authors' contributions}

All authors actively participated in the design and implementation of the study. All authors conceived and designed the analysis; JS collected the data; MM, LG and PG contributed data and analysis tools; JS performed the statistical analysis. All authors wrote the final manuscript. All authors read and approved the final manuscript.

\section{Competing interests}

The authors declare that they have no competing interests.

\section{Appendix}

See Tables 8, 9, 1011 and Figs. 5, 6.

\section{Funding}

Not applicable.

\section{Availability of data and materials}

The raw data corresponds to national household surveys, whose microdata sets are publicly available. The specific processed datasets used in the study are available from the corresponding author upon request.

Table 8 National household surveys used in this study

\begin{tabular}{|c|c|c|c|}
\hline Country & Survey name & Acronym & Surveys used \\
\hline \multirow[t]{2}{*}{ Argentina } & Encuesta Permanente de Hogares Puntual & $\mathrm{EPH}$ & $1992-2003$ \\
\hline & Encuesta Permanente de Hogares Contínua & $\mathrm{EPH}-\mathrm{C}$ & $2003-2014$ \\
\hline \multirow[t]{4}{*}{ Bolivia } & Encuesta Integrada de Hogares & $\mathrm{ElH}$ & 1992,1993 \\
\hline & Encuesta Nacional de Empleo & ENE & 1997 \\
\hline & Encuesta Contínua de Hogares & $\mathrm{ECH}$ & 1999,2000 \\
\hline & Encuesta de Hogares & $\mathrm{EH}$ & $2001,2002,2005,2007-2009,2011-2013$ \\
\hline Brazil & Pesquisa Nacional por Amostra de Domicilios & PNAD & 1988-1993, 1995-1999, 2001-2009, 2011-2014 \\
\hline Chile & Encuesta de Caracterización Socioeconómica Nacional & CASEN & $\begin{array}{l}\text { 1987, 1990, 1992, 1994, 1996, 1998, 2000, 2003, } \\
\text { 2006, 2009, 2011, } 2013\end{array}$ \\
\hline \multirow[t]{2}{*}{ Colombia } & Encuesta Continua de Hogares & $\mathrm{ECH}$ & $2001-2005$ \\
\hline & Gran Encuesta Integrada de Hogares & GEIH & $2008-2014$ \\
\hline \multirow[t]{2}{*}{ Costa Rica } & Encuesta de Hogares de Propósitos Múltiples & EHPM & 1989-2009 \\
\hline & Encuesta nacional de hogares & ENAHO & $2010,2012-2014$ \\
\hline Dominican Rep. & Encuesta Nacional de Fuerza de Trabajo & ENFT & $2000-2014$ \\
\hline \multirow[t]{2}{*}{ Ecuador } & Encuesta de Condiciones de Vida & ECV & 1994, 1995, 1998, 1999, \\
\hline & Encuesta Nacional de Empleo, Desempleo y Subempleo & ENEMDU & $2003-2014$ \\
\hline El Salvador & Encuesta de Hogares de Propósitos Múltiples & EHPM & 1991, 1995, 1996, 1998-2014 \\
\hline Guatemala & Encuesta Nacional sobre Condiciones de Vida & ENCOVI & 2000, 2006, 2011 \\
\hline Honduras & Encuesta Permanente de Hogares de Propósitos Múltiples & EPHPM & $1991-1999,2001-2013$ \\
\hline Mexico & Encuesta Nacional de Ingresos y Gastos de los Hogares & ENIGH & $\begin{array}{l}1989,1992,1994,1996,1998,2000,2002 \\
2004-2006,2008,2010,2012,2014\end{array}$ \\
\hline Nicaragua & $\begin{array}{l}\text { Encuesta Nacional de Hogares sobre } \\
\text { Medición de Nivel de Vida }\end{array}$ & EMNV & 1993, 1998, 2001, 2005, 2009 \\
\hline \multirow[t]{2}{*}{ Panama } & Encuesta de Hogares, Mano de Obra & $\mathrm{EMO}$ & 1989,1991 \\
\hline & Encuesta de Hogares & $\mathrm{EH}$ & $1995,1997-2012$ \\
\hline \multirow[t]{3}{*}{ Paraguay } & Encuesta de Hogares (Mano de Obra) & $\mathrm{EH}$ & 1990 \\
\hline & Encuesta Integrada de Hogares & $\mathrm{ElH}$ & 1997, 2001 \\
\hline & Encuesta Permanente de Hogares & $\mathrm{EPH}$ & $1999,2002-2014$ \\
\hline Peru & Encuesta Nacional de Hogares & ENAHO & $1997-2014$ \\
\hline Uruguay & Encuesta Continua de Hogares & $\mathrm{ECH}$ & $\begin{array}{l}\text { 1989, 1992, 1995-1998, } \\
\text { 2000-2014 }\end{array}$ \\
\hline Venezuela & Encuesta de Hogares Por Muestreo & EHM & 1989, 1992, 1995, 1997-2011 \\
\hline
\end{tabular}

Source: own elaboration 


\section{Table 9 Composition of the panel datasets used in this study}

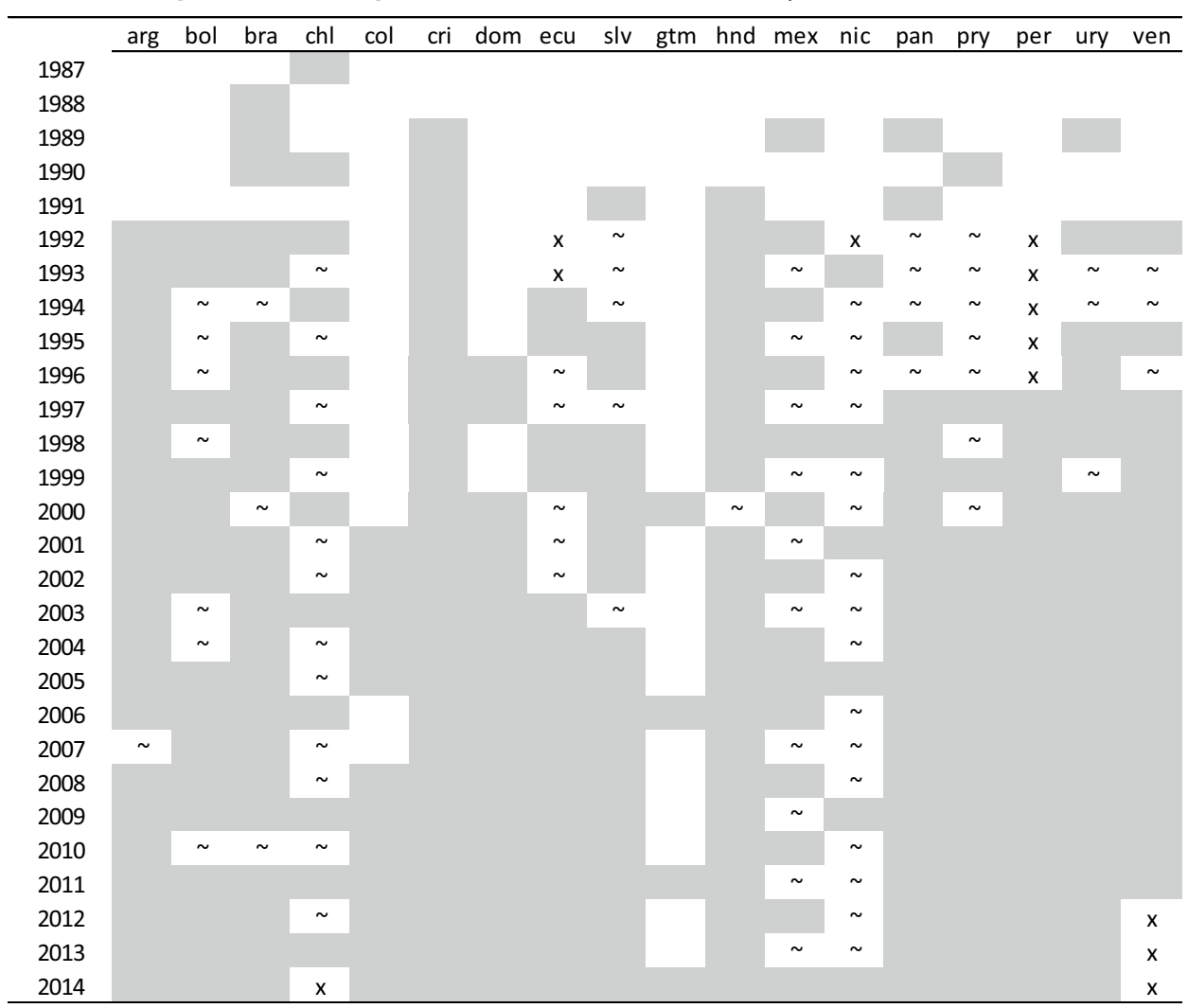

The shaded cells correspond to the available surveys, which constitute the unbalanced panel that we use in the econometric estimates. The cells marked with the $\sim$ and $\mathrm{x}$ signs are interpolated and extrapolated data, respectively, used to compute the descriptive statistics for the Latin American average in Sect. 4. Note that the Latin American average excludes Colombia, Dominican Republic, and Guatemala 
Table 10 Description and sources of variables used in this study

\begin{tabular}{|c|c|c|}
\hline Variable & Description & Source \\
\hline Female labor force participation & $\begin{array}{l}\text { Female labor force participation as percentage of } \\
\text { women aged } 25-54\end{array}$ & National household surveys \\
\hline Male labor force participation & $\begin{array}{l}\text { Male labor force participation as percentage of } \\
\text { men aged } 25-54\end{array}$ & National household surveys \\
\hline Labor force participation ratio (men/women) & LFP ratio (men/women) expressed in percentage & National household surveys \\
\hline Log GDP per capita & Real gross domestic product per capita (log) & WDI Database, World Bank \\
\hline CCTs coverage & $\begin{array}{l}\text { Share of total population who are beneficiaries of } \\
\text { conditional income transfer programs }\end{array}$ & $\begin{array}{l}\text { CCTs beneficiaries: own elaboration based on data } \\
\text { from ECLAC. Population: WDI Database, World } \\
\text { Bank }\end{array}$ \\
\hline Male unemployment & Unemployment rate for men aged 25-54. & National household surveys \\
\hline Years of education & Average of years of education (log) & National household surveys \\
\hline Number of children & Average number of children (log) & National household surveys \\
\hline Married women & Share of married women aged 25-54 & National household surveys \\
\hline Women in charge of old person & $\begin{array}{l}\text { Share of women who are in charge of old persons } \\
(>70 \text { years old })\end{array}$ & National household surveys \\
\hline Age of children & Average age of children in household & National household surveys \\
\hline Hourly wage gap (men/women) & $\begin{array}{l}\text { Gender ratio of average hourly labor income of the } \\
\text { main job, PPP adjusted. (men/women) }\end{array}$ & National household surveys \\
\hline Female hourly wage & $\begin{array}{l}\text { Hourly labor income of the main job of women, } \\
\text { PPP adjusted }\end{array}$ & National household surveys \\
\hline Service sector (value added) & Value added of service sector (share of GDP) & WDI Database, World Bank \\
\hline Rural population & Rural population as share of total population & WDI Database, World Bank \\
\hline Index of exports prices & $\begin{array}{l}\text { Value index of exports (f.o.b.) converted to U.S. } \\
\text { dollars and expressed as a percentage of the } \\
\text { average for the base period (2010) }\end{array}$ & UNCTAD \\
\hline
\end{tabular}

Table 11 Mean of main variables

\begin{tabular}{|c|c|c|c|c|c|c|c|c|c|c|}
\hline & LFP & & Employn & & Unempl & nent & GDP (log) & CCTs coverage & Service sector & Rural pop. \\
\hline & Women & Men & Women & Men & Women & Men & & & & \\
\hline Argentina & 67.1 & 94.1 & 62.7 & 89.6 & 6.6 & 4.8 & 16.0 & 27.4 & 62.9 & 8.4 \\
\hline Bolivia & 73.8 & 97.0 & 71.0 & 94.9 & 3.7 & 2.2 & 4.8 & 26.8 & 50.2 & 31.9 \\
\hline Brazil & 71.2 & 92.4 & 66.4 & 89.0 & 6.8 & 3.7 & 12.4 & 26.5 & 70.8 & 14.6 \\
\hline Chile & 64.3 & 92.3 & 60.2 & 87.6 & 6.3 & 5.1 & 16.4 & 4.1 & 61.7 & 10.8 \\
\hline Colombia & 72.9 & 96.1 & 66.2 & 91.1 & 9.2 & 5.2 & 9.5 & 10.1 & 58.0 & 23.8 \\
\hline Costa Rica & 62.2 & 94.9 & 56.9 & 89.6 & 8.4 & 5.6 & 11.0 & 3.6 & 69.4 & 24.1 \\
\hline Dominican Rep. & 57.8 & 90.3 & 55.1 & 88.4 & 4.6 & 2.1 & 8.7 & 23.4 & 66.9 & 21.9 \\
\hline Ecuador & 63.3 & 96.7 & 60.8 & 94.5 & 4.0 & 2.3 & 8.5 & 17.4 & 51.8 & 36.5 \\
\hline El Salvador & 61.3 & 92.8 & 59.8 & 89.3 & 2.5 & 3.8 & 6.7 & 2.8 & 61.9 & 33.7 \\
\hline Guatemala & 50.1 & 96.5 & 49.4 & 95.3 & 1.4 & 1.3 & 6.2 & 24.7 & 59.6 & 48.9 \\
\hline Honduras & 57.6 & 94.8 & 54.1 & 91.3 & 6.0 & 3.7 & 3.9 & 44.2 & 59.8 & 45.9 \\
\hline Mexico & 58.5 & 96.2 & 57.0 & 91.8 & 2.5 & 4.5 & 14.7 & 22.5 & 62.2 & 21.0 \\
\hline Nicaragua & 62.7 & 95.5 & 59.3 & 91.7 & 5.4 & 4.0 & 3.6 & 2.6 & 54.2 & 41.5 \\
\hline Panama & 66.4 & 96.6 & 63.3 & 94.2 & 4.6 & 2.5 & 12.6 & 3.3 & 69.6 & 33.7 \\
\hline Paraguay & 69.5 & 95.4 & 65.6 & 92.4 & 5.6 & 3.1 & 6.6 & 8.4 & 50.6 & 40.6 \\
\hline Peru & 79.4 & 95.3 & 77.6 & 93.7 & 2.2 & 1.6 & 7.8 & 10.5 & 57.6 & 21.7 \\
\hline Uruguay & 79.6 & 96.0 & 74.5 & 93.0 & 6.4 & 3.1 & 14.0 & 7.9 & 64.2 & 4.8 \\
\hline Venezuela & 68.0 & 95.4 & 63.0 & 90.0 & 7.4 & 5.7 & 15.6 & & 42.1 & 11.2 \\
\hline Latin America & 65.9 & 94.9 & 62.4 & 91.5 & 5.2 & 3.6 & 9.9 & 15.6 & 59.6 & 26.4 \\
\hline
\end{tabular}

The table shows averages over the period available for each country. Labor force participation (LFP) and employment as percentage of adults aged $25-54$. Unemployment rate for adults aged 25-54. Real GDP in logs. CCTs coverage as the percentage of total population who are beneficiaries. Value added of Service Sector as percentage of GDP. Rural population as percentage of total population 


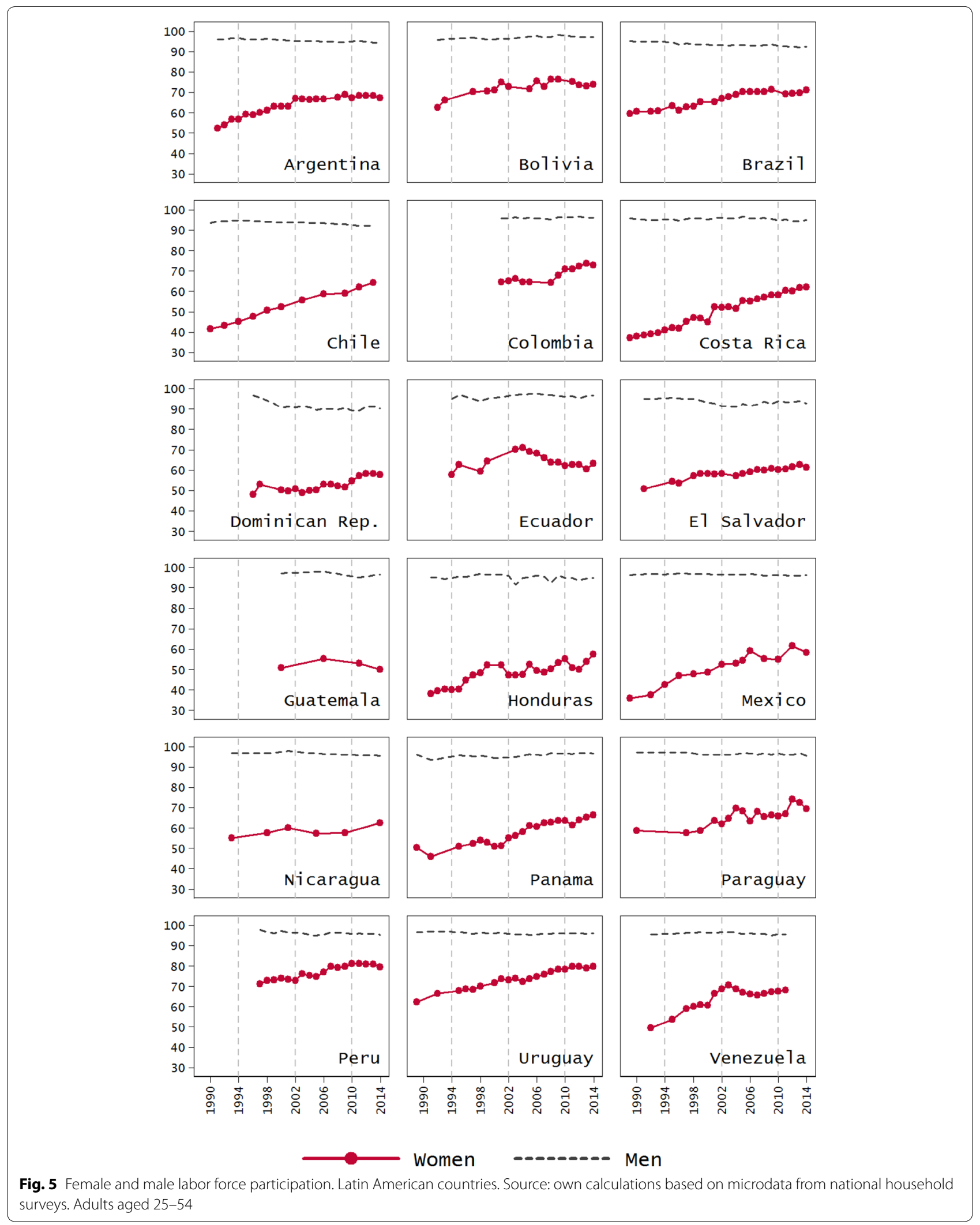




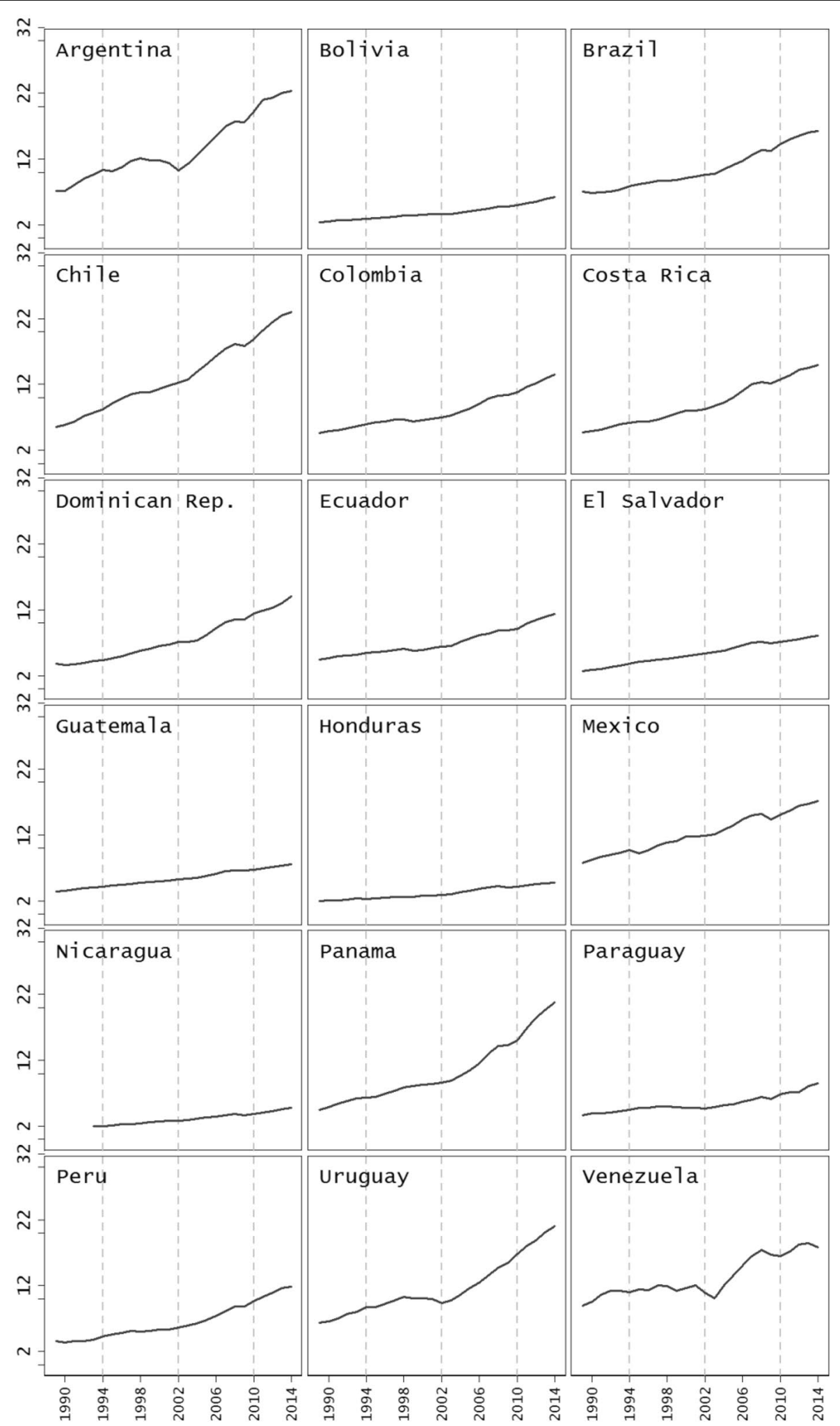

Fig. 6 Per capita GDP. Latin American countries. Source: own calculations based on data from WDI Database. Note: per capita GDP in thousands of PPP-adjusted 2011 US\$ 


\section{Author details}

${ }^{1}$ Centro de Estudios Distributivos, Laborales y Sociales (CEDLAS), IIE-FCE, Universidad Nacional de La Plata, and CONICET, La Plata, Argentina. ${ }^{2}$ Departamento de Economía, FCE-UNLP, Oficina 322, Calle 6 No 777, 1900 La Plata, Argentina.

Received: 29 August 2018 Accepted: 21 September 2019 Published online: 16 October 2019

\section{References}

Arellano, M., Bond, S.: Some tests of specification for panel data: Monte Carlo evidence and an application to employment equations. Rev. Econ. Stud. 58, 277-297 (1991)

Ashenfelter, O.: Unemployment as disequilibrium in a model of aggregate labor supply. Econometrica 48(3), 547-564 (1980)

Attanasio, O., Levell, P., Low, H., Sánchez-Marcos, V.: Aggregating elasticities: intensive and extensive margins of female labour supply. NBER Working Papers 21315, National Bureau of Economic Research, Inc (2015)

Basu, K., Genicot, G., Stiglitz, J.E.: Unemployment and wage rigidity when labor supply is a household decision. Working papers 00-10, Cornell University, Center for Analytic Economics (2000)

Baxter, M., King, R.G.: Measuring business cycles: approximate band-pass filters for economic time series. Review of economics and statistics, MIT Press, 81(4) (1999)

Beccaria, L., Maurizio, R., Vázquez, G.: El estancamiento de la tasa de participación económica femenina en Argentina en los 2000 s. Mimeo (2015)

Besley, T.J., Persson, T.: The incidence of civil war: theory and evidence. Working paper 14585, National Bureau of Economic Research (2008)

Bhalotra, S.R., Umaña-Aponte, M.: The dynamics of women's labour supply in developing countries. IZA discussion papers 4879, Institute for the Study of Labor (IZA) (2010)

Bredtmann, J., Otten, S., Rulff, C.: Husband's unemployment and wife's labor supply: the added worker effect across Europe. ILR Review, pp. 1-31 (2017)

Brückner, M., Ciccone, A.: International commodity prices, growth and the outbreak of civil war in sub-saharan Africa. Econ. J. 120(544), 519-534 (2010)

Busso, M., Romero Fonseca, D.A.: Determinants of female labor force participation. In: Gasparini, L., and Marchionni, M., editors, Bridging gender gaps? The rise and deceleration of female labor force participation in Latin America, volume 1, chapter 6, pp. 199-260. Center for Distributive, Labor and Social Studies, 1st edition (2015)

Cerrutti, M.: Economic reform, structural adjustment and female labor force participation in Buenos Aires, Argentina. World Dev. 28(5), 879-891 (2000)

Chioda, L.: Work and family: Latin American \& Caribbean Women in Search of a New Balance. World Bank, Washington, DC (2011)

Christiano, L.J., Fitzgerald, T.J.: The band pass filter. Int. Econ. Rev. 44(2), 435-465 (2003)

Cox Edwards, A., Roberts, J.: The effects of structural adjustment on women in Latin America. In: Horton, S., Kanbur, R., Mazumdar, D., (eds.) Labor markets in an era of adjustment, vol. 1. Washington, DC: World Bank, 1st edition (1994)

Cullen, J.B., Gruber, J.: Does unemployment insurance crowd out spousal labor supply? J. Labor Econ. 18(3), 546-572 (2000)

Darby, J., Hart, R., Vecchi, M. (2001), Labour force participation and the business cycle: a comparative analysis of France, Japan, Sweden and the United States, Japan and the World Economy, 13(2), pp. 113-133. Dell, M., Jones, B. F., and Olken, B. A: Temperature Shocks and Economic Growth: evidence from the Last Half Century. American Economic Journal: Macroeconomics 4(3), 66-95 (2012)

Eissa, N., Hoynes, H.: Taxes and the labor market participation of married couples: the earned income tax credit. Journal of Public Economics, Elsevier 88(9-10), 1931-1958 (2004)

Elborgh-Woytek, K., Newiak, M., Kochhar, K., Fabrizio, S., Kpodar, K., Wingender, P., Clements, B.J., Schwartz, G.: Women, work, and the economy; macroeconomic gains from gender equity, IMF Staff Discussion Notes 13/10, International Monetary Fund (2013)
Erten, B., Ocampo, J.A.: Super cycles of commodity prices since the mid-nineteenth century. World Dev. 44, 14-30 (2013)

Fernandes, R., Felicio, F.: The entry of the wife into the labor force in response to the husband's unemployment: a study of the added worker effect in Brazilian metropolitan areas. Econ. Dev. Cult. Change 53(4), 887-911 (2005)

Garcia-Perez, J.I., Rendon, S.,: Family job search and wealth: the added worker effect revisited, working papers 16-34, Federal Reserve Bank of Philadelphia (2016)

Garganta, S., Gasparini, L., Marchionni, M.: Cash transfers and female labor force participation: the case of AUH in Argentina. IZA J. Labor Policy 6, 10 (2017). https://doi.org/10.1186/s40173-017-0089-x

Gasparini, L., Marchionni, M.: Deceleration in female labor force participation in Latin America. Econ.-LACEA J. 18(1), 197-224 (2017)

Gasparini, L., Marchionni, M. (eds.): Bridging gender gaps? The rise and deceleration of female labor force participation in Latin America. Center for Distributive, Labor and Social Studies, La Plata, Buenos Aires, Argentina, 1 edition. https://goo.gl/yeEQZM (2015)

Gasparini, L., Marchionni, M., Badaracco, N., Serrano, J.: Characterizing female participation changes. In: Gasparini, L., Marchionni, M., (eds.) Bridging gender gaps? The rise and deceleration of female labor force participation in Latin America, vol. 1, chapter 4, pp. 199-260. Center for Distributive, Labor and Social Studies, 1st edition (2015)

Gómez, V:: The use of butterworth filters for trend and cycle estimation in economic time series. J. Bus. Econ. Stat. 19(3), 365-373 (2001)

Heckman, J.J., Macurdy, T.E.: A life cycle model of female labour supply. Rev. Econ. Stud. 47(1), 47-74 (1980)

Hodrick, R., Prescott, E.: Postwar U.S. business cycles: an empirical investigation. J. Money Credit Bank. 29(1), 1-16 (1997)

Kimmel, J.: Childcare costs as a barrier to employment for single and married mothers. Rev. Econ. Stat. 80(2), 287-299 (1998)

Layard, R., Barton, M., Zabalza, A.: Married women's participation and hours. Economica 47(185), 51-72 (1980)

Lee, G.H., Parasnis, J.: Discouraged workers in developed countries and added workers in developing countries? Unemployment rate and labour force participation. Econ. Model. 41(C), 90-98 (2014)

Lundberg, S.: The added worker effect. J. Labor Econ. 3(1), 11-37 (1985)

Maloney, T.: Employment constraints and the labor supply of married women: a reexamination of the added worker effect. J. Hum. Resour. 22(1), 51-61 (1987)

Maloney, T.: Unobserved variables and the elusive added worker effect. Economica 58(230), 173-187 (1991)

Maloney, W.F.: Informality revisited. World Dev. 32(7), 1159-1178 (2004)

Mankart, J., Oikonomou, R.: Household search and the aggregate labour market. Rev. Econ. Stud. 84(4), 1735-1788 (2017)

Martinoty, L.: Intra-household coping mechanisms in hard times: the added worker effect in the 2001 Argentine Economic Crisis. Working paper, working paper GATE 2015-05 (2015)

McGuirk, E., Burke, M.: Economic shocks and varieties of conflict: global prices, real income and local violence in Africa. Miemo. SSRN: https://ssrn.com/ abstract $=2776263(2016)$

McKenzie, D.J.: How do households cope with aggregate shocks? Evidence from the Mexican Peso crisis. World Dev. 31(7), 1179-1199 (2003)

McKenzie, D.J.: Aggregate shocks and urban labor market responses: evidence from Argentina's financial crisis. Econ. Dev. Cult. Change 52(4), 719-758 (2004)

Michalopoulos, C., Robins, P., Garfinkel, I.: A structural model of labor supply and childcare demand. J. Hum. Resour. 27(1), 166-203 (1992)

Naz, G.: The impact of cash-benefit reform on parents' labour force participation. J. Popul. Econ. 17(2), 369-383 (2004)

Ocampo, J.A.: Commodity-led development in Latin America. In: Alternative pathways to sustainable development: lessons from Latin America, International Development Policy series No. 9 (Geneva, Boston: Graduate Institute Publications, Brill-Nijhoff), pp. 51-76 (2017)

Parada, C., Alejo, J., Gasparini, L.: Distributive implications of changing female employment. Revista Cuadernos de Economía, in press (2017)

Parker, S., Skoufias, E.: The added worker effect over the business cycle: evidence from urban Mexico. Appl. Econ. Lett. 11(10), 625-630 (2004)

Paz, J.A.: El Efecto del Trabajador Adicional: evidencia para Argentina (2003-2007). Cuadernos de economía 46, 225-241 (2009) 
Peña, X., Bernal, R., Amador, D.: The rise in female participation in Colombia: fertility, marital status or education? Ensayos sobre política económica 31(71), 54-63 (2013)

Prieto-Rodriguez, J., Rodriguez-Gutierrez, C.: Participation of married women in the European labor markets and the "added worker effect". J. Socio-Econ. 32(4), 429-446 (2003)

SEDLAC:: Socioeconomic Database for Latin America and the Caribbean. Technical report, CEDLAS-World Bank (2014)

Stampini, M, Tornarolli, L. The growth of conditional cash transfers in Latin America and the Caribbean: did they go too far? IZA Policy Papers 49, Institute for the Study of Labor (IZA) (2012)

Stephens, M.: Worker displacement and the added worker effect. J. Labor Econ. 20(3), 504-537 (2002)

Tachibanaki, T., Sakurai, K.: Labour supply and unemployment in Japan. Eur. Econ. Rev. 35(8), 1575-1587 (1991)

Tamm, M.: Child benefit reform and labor market participation, p. 97. Ruhr Econ. Pap., No (2009)
Tsani, S., Paroussos, L., Fragiadakis, C., Charalambidis, I., Capros, P.: Female labour force participation and economic growth in the South Mediterranean countries. Econ. Lett. 120(2), 323-328 (2013)

World Bank.: The effects of women's economic power in Latin America and the Caribbean. Technical Report 21315, Poverty and Labor Brief-LAC region (2012)

Woytinsky, W.S.: Additional workers and the volume of unemployment in the depression. Pamphlet series 1, Washington: Social Science Research Council, Committee on Social Security (1940)

\section{Publisher's Note}

Springer Nature remains neutral with regard to jurisdictional claims in published maps and institutional affiliations.

\section{Submit your manuscript to a SpringerOpen ${ }^{\circ}$ journal and benefit from:}

- Convenient online submission

- Rigorous peer review

- Open access: articles freely available online

- High visibility within the field

- Retaining the copyright to your article

Submit your next manuscript at $\gg$ springeropen.com 